\title{
Investigations Upon the Water Movements in the English Channel. Summer, 1924.
}

\author{
By \\ J. N. Carruthers, \\ Fisheries Laboratory, Lowestoft. \\ With 11 Charts.
}

Review of Previous Investigations and their Results.

The conspicuous success of Fulton's experiments with floating drift bottles in the northern North Sea $(\mathbf{1})^{*}$ gave a marked impetus to the study of marine currents by means of freely moving objects (both surface floating and bottom trailing). Finding that Fulton's results, "laissaient encore indécise la question des rapports de la Mer du Nord avec la Manche" (2, p. 55), Gilson, in 1899, carried out his well-known investigations with floating bottles in the south-west part of the Southern Bight (3). He used bottles of two kinds, simple and coupled, and put them out at different states of the tide. In 1897 the surface drift of the English Channel had been investigated by the Marine Biological Association, floating bottles being put out to the number of 430 during the year. The results of these investigations are to be found in a paper by Garstang (4). In 1911 the Board of Agriculture and Fisheries also made experiments with drift bottles; these threw light upon the water movements in the North Sea-English Channel junction area. The chief results of these latter experiments are embodied in Admiralty Chart 327. Further small bottle experiments have been made since by the Ministry of Agriculture and Fisheries, chiefly in definite connection with specific fishery research problems.

An account of these latter experiments has been given in reports devoted to researches on young herring (5).

As is well known, our knowledge of the water movements in the English Channel and its junction area with the North Sea is largely based upon researches into the distribution of waters of different salinity and temperature. Extensive data on salinity distribution have been amassed over a considerable period of years, and the consideration thereof has yielded valuable information as to the movements of the water in our area. It

* Bracketed numbers refer to th 3 list of literature cited ; this appears at the end of the paper.

NEW SERIES.-VOL. XIV. NO. 3. MARCH, 1927. 
is not our intention to refer in any detail to the numerous researches of this kind which have been carried out; the chief workers in this field have been Matthews, Jee, Lumby, and Harvey. The last-named writer has recently published a comprehensive review of the many researches which various workers have made upon the Hydrography of the English Channel (6). Harvey there gives a most valuable survey of the present state of knowledge, and the full bibliography provided by him in his paper renders unnecessary any exhaustive list of references here. We shall here merely indicate the broad features of the water movements in the English Channel, so that it may be possible to realise to what extent the investigations which are the subject of this paper have added to our knowledge.

In addition to the results gained from the experiments with drift bottles and the researches on salinity distribution, mention should be made of an attempt by Gehrke (7), using Knudsen's Hydrographical Theorem (vide 8, p. 692), to estimate the net flow of water through the Channel. Current measurements made at the Varne Lightvessel for fortnightly periods in the years 1911, 1912, and 1913, afforded useful information as to the water movements at different depths in the eastern end of the Channel. At the present time current measurements are being continuously carried out at the lightvessel just mentioned. The results of numerous log-ship observations made on the Sandettie Lightvessel and reported upon by Heldt (9) have served further to extend our insight into the current régime of the Dover Straits area, whilst Wollaston's investigations upon the distribution and drift of Plaice eggs have been useful in a similar connection.

The water movements of the southern North Sea have recently been extensively investigated by means of drift bottles by the Ministry of Agriculture and Fisheries; the experiments were reported on by the present writer (10). In this latter connection it might be stated that the movements of those bottles put out at the Sandettie Lightvessel were made the subject-matter of a separate short paper (11). Bidder's wellknown experiments with bottom bottles (12) also served to indicate what were the movements of the bottom water in the southern part of the North Sea.

All the foregoing researches were fully considered by Harvey when his comprehensive survey was made (6), and occasional reference to his paper assists us to present a very brief and broad picture of the water movements in the English Channel.

There is evidence that bottom water passes up the Channel into the North Sea (at any rate at certain seasons), for bottom-trailing bottles liberated in the Channel have been recovered in the North Sea. Gehrke's calculations, already referred to, point to a similar 
conclusion. It seems probable, that this east-going bottom current rises to the surface in the eastern part of the Channel $(\mathbf{1 3}, \mathrm{p}$. 5) where the water is much shallower than it is farther westward. There is a pronounced surface drift from west to east along the length of the Channel. This surface "current" is supposed by some workers to be due entirely to the wind-which is predominantly southwesterly. It is well known, as a result of numerous current observations at the Varne Lightvessel, that the occurrence of winds blowing persistently from the east can hold up and reverse the direction of water movement so as to bring about a movement of the surface waters into the Channel from the southern North Sea. This state of affairs has been experienced fairly often in the course of the last two years, but the "North Sea to Channel " current is only of temporary persistence, and with the disappearance of the easterly winds the east-north-easterly current reasserts itself. It has been deemed a moot point whether the surface waters of the Channel would be devoid of an easterly movement in the absence of the wind effect.

Harvey (6, p. 66) calculates that the mean value of the speed of flow of the water in the Channel between the mouth and Dover Straits is 1.6 miles a day. During January, 1923 (see 5), bottom bottles moved from the longitude of the Isle of Wight towards the North Sea at the rate of $1 \frac{1}{2}$ miles a day - whilst many records exist of surface bottles moving eastwards at a speed of as much as 6 miles a day.

It was felt to be desirable that experiments with bottles should be carried out in the Summer, to see how the results compared with those of certain experiments which had chanced to be made in Winter to assist in researches made upon the distribution of herring fry.

It was decided that bottles should be put out at the International Stations E2 and E3, and also that as good a distribution of bottles as possible should be made along the steamship route, Southampton to St. Malo. The Marine Biological Association at Plymouth and the Ministry of Agriculture and Fisheries were to be jointly concerned in the experiment. During the first half of July, 1924, the following liberations were made in the English Channel west of the Isle of Wight :-

1. Fifty surface and 50 bottom bottles at Station E2 $\left(49^{\circ} 27^{\prime}\right.$ N.$4^{\circ} 42^{\prime}$ W.).

(These bottles were put out on 9.7.24 from the s.D. Salpa by the Marine Biological Association.)

2. Fifty surface and 50 bottom bottles at Station E3 $\left(48^{\circ} 34^{\prime}\right.$ N.$5^{\circ} 13^{\prime}$ W.).

(These bottles also were put out from the s.D. Salpa by the Marine Biological Association on 10.7.24.) 
3. Fifty surface and 50 bottom bottles at equal intervals between $50^{\circ} 20^{\prime} \mathrm{N}$. and $50^{\circ} 5^{\prime} \mathrm{N}$. on the night $10 / 11.7 .24$.

(These bottles were put out from the Southern Railway Company's s.s. Lorina on her passage between Southampton and St. Malo.)

4. Fifty surface and 50 bottom bottles at equal intervals between $49^{\circ} 35^{\prime} \mathrm{N}$. and $49^{\circ} 20^{\prime} \mathrm{N}$.

(Put out from s.s. Lorina on passage between Southampton and St. Malo on night of $10 / 11.7 .24$.)

5. Fifty surface and 50 bottom bottles at equal intervals between $49^{\circ} 0^{\prime}$ N. and $48^{\circ} 50^{\prime}$ N. (per s.s. Lorina on $10 / 11.7 .24$ )

When reporting upon the results obtained from a large-scale drift bottle experiment, it is desirable to condense the records in some manner which, whilst masking no features of real interest, shall render the records " manageable." In a former large experiment it was possible to present all the individual records in tabulated form on the basis of direction travelled; all bottles recovered were referred to direction sectors comprehending $\frac{1}{16}$ th part of the compass. These direction sectors were suitably superscribed on a chart, so that, for instance, the sector labelled "E.N.E." straddled $11_{4}^{1}$ " on each side of the actual direction E.N.E.

This procedure was well suited to the reporting upon experiments carried out in the North Sea, but in an area like the Channel it would, for many obvious reasons, be inconvenient. We do not, however, wish to present the details as to positions of recovery of the bottles in the form of a clumsy table of latitudes and longitudes - the method we adopt must be such that it will be an easy matter to refer the stated positions of recovery to a chart, so that a mental picture of the movements of a particular bottle may readily be formed. It is clear that we must set out the individual bottle histories in a report of the experiments under review since so few bottles are involved.

The following procedure has accordingly been adopted in reporting :-

A chart of sufficient geographical range was prepared embracing the whole of the English Channel, the North Sea as far north as the Shetlands, and the Cattegat - with the Belts. On this chart were superscribed the ordinary statistical rectangles, each rectangle being delimited by one degree of longitude and one-half a degree of latitude. The positions of recovery of the bottles were (as the records were received) referred to and tabulated in terms of these statistical rectangles. For greater precision in the statement of results, the rectangles were visually divided up 
into sub-rectangles after the manner of Army cartography practice, thus :-

the rectangle

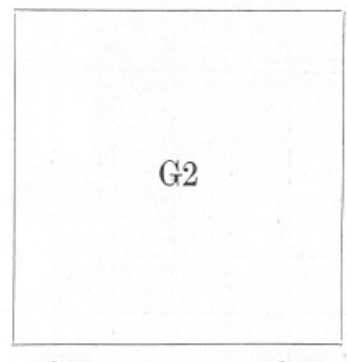

$52^{\circ} \mathrm{N}$.

$51 \frac{1}{2}^{\circ} \mathrm{N}$

$2^{\circ} \mathrm{E} . \quad 3^{\circ} \mathrm{E}$.

can be considered to be subdivided thus :-

\begin{tabular}{|c|c|c|}
\hline$a$ & $b$ & $c$ \\
\hline$d$ & $e$ & $f$ \\
\hline$g$ & $h$ & $j$ \\
\hline
\end{tabular}

so that the position of recovery of a bottle might be tabulated as :-

G2 g,

and the latter can be much more quickly referred to a chart than could the usual co-ordinates of latitude and longitude. Chart 1 shows the positions at which bottles were put out ; it is also divided up in the manner described to serve reference requirements for the recovery positions of the bottles.

For purposes of tabulation of results, a "shorthand method" of referring to the positions of liberation was also required. The International Stations at which the Marine Biological Association put out bottles are referred to in what follows by their ordinary names-E2 and E3.

The three liberation "stretches" on the Southampton to St. Malo route are thus referred to :-

$$
\begin{array}{llll}
\text { Northernmost stretch } & . & \text {. } & \text { S.SM(a). } \\
\text { Mid-Channel } & \text {. } & \text {. } & \text { S.SM(b). } \\
\text { Southernmost }, " & . & \text {. } & \text { S.SM(c). }
\end{array}
$$

and these symbols appear on the chart. 


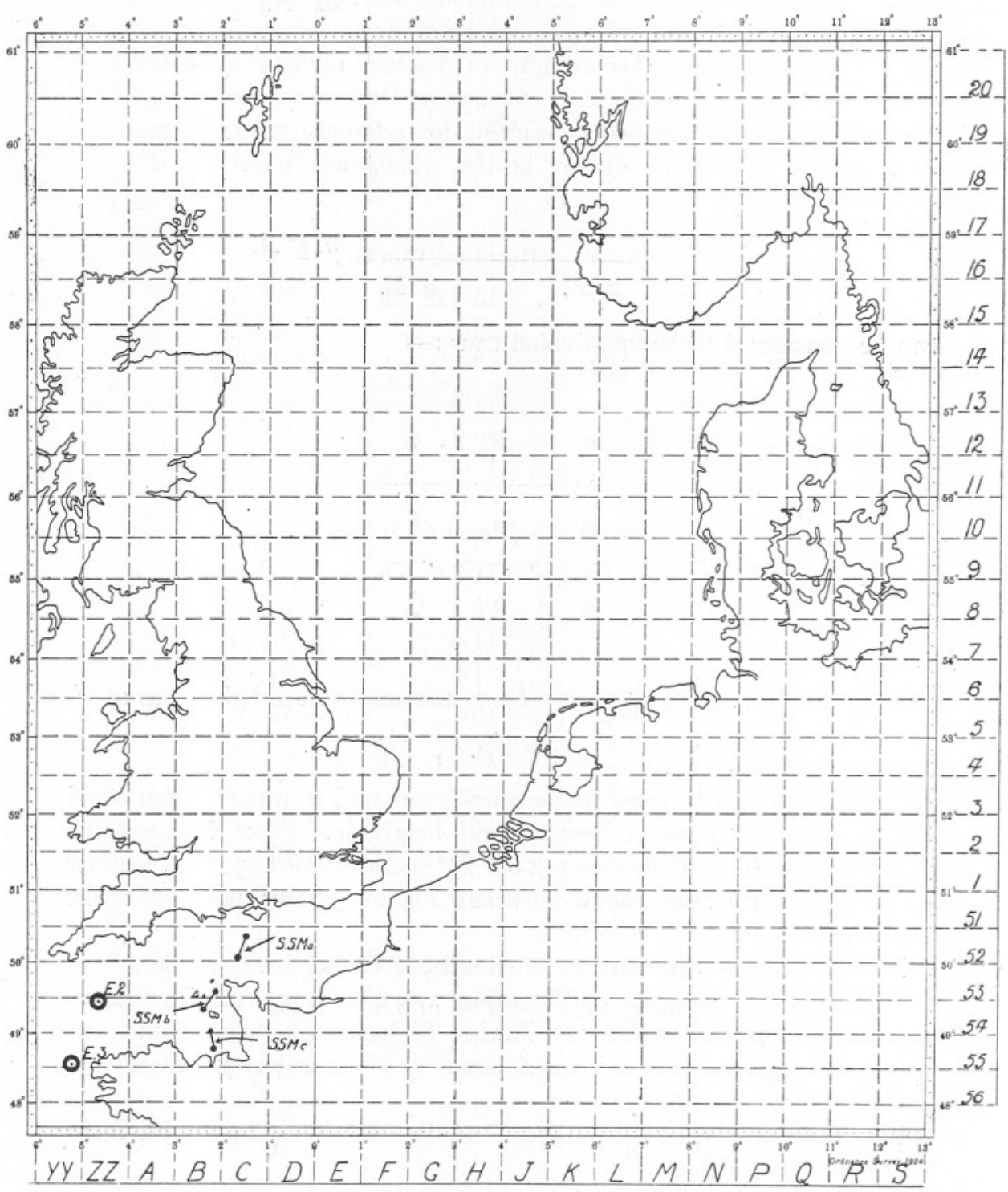

CHART 1.

Key Chart to which tabulated recovery positions of bottles may be referred. 
Enough is known as to the effect of wind on the movements of the surface water to realise the necessity for an adequate study of prevailing wind conditions. Such a study was made, and it is convenient to give the results here, so that reference can be made to them when discussing the bottle movements. Accordingly we give here relevant meteorological details for the stations :- Scilly, Guernsey, Dungeness, and Great Yarmouth - the two latter being desirable for reference when we are considering the movements of any bottles which may penetrate into the North Sea.

\section{ScIlly. (Residual Winds.)}

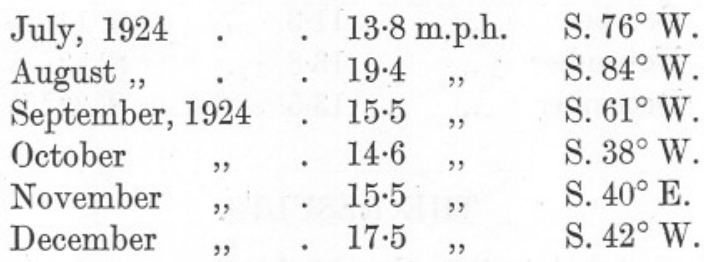

Guernsey. (Residual Winds.)

\begin{tabular}{|c|c|c|c|c|c|c|}
\hline \multicolumn{4}{|c|}{ (4-10) July, 1924} & \multicolumn{2}{|c|}{$11 \cdot 7$ m.p.h. } & S. $67^{\circ} \mathrm{W}$. \\
\hline$(11-17)$ & , & , & & $6 \cdot 2$ & ", & S. $53^{\circ} \mathrm{W}$. \\
\hline$(18-24)$ & , & , & & $11 \cdot 9$ & , & S. $83^{\circ} \mathrm{W}$. \\
\hline$(25-31)$ & ", & ", & & $11 \cdot 4$ & , & S. $81^{\circ} \mathrm{W}$. \\
\hline \multicolumn{3}{|c|}{ Month of July } & & $10 \cdot 1$ & $"$ & $.73^{\circ}$ \\
\hline \multicolumn{3}{|c|}{ (1-7) August, 1924} & & \multicolumn{2}{|c|}{11.5 m.p.h. } & $88^{\circ}$ \\
\hline (8-14) & & , & & $2 \cdot 1$ & 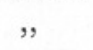 & . \\
\hline (15-21) & , & , & & $18 \cdot 5$ & , & \\
\hline (22-28) & " & " & & 15 & ", & No. \\
\hline \multicolumn{3}{|c|}{ Month of August } & & $12 \cdot 0$ & , & $.84^{\circ}$ \\
\hline
\end{tabular}

Dungeness. (Residual Winds.)

\begin{tabular}{|c|c|c|c|c|c|c|}
\hline$(4-10)$ & July & 24 & & $12 \cdot 8$ & o.h. & S. $62^{\circ} \mathrm{W}$. \\
\hline$(11-17)$ & , & , & & $4 \cdot 3$ & , & S. $67^{\circ} \mathrm{W}$. \\
\hline$(18-24)$ & ", & & & $6 \cdot 8$ & ", & N. $79^{\circ} \mathrm{W}$ \\
\hline$(25-31)$ & , & & & $7 \cdot 5$ & ", & S. $61^{\circ} \mathrm{W}$. \\
\hline Month o & $f J u$ & & & $7 \cdot 5$ & , & S. $70^{\circ} \mathrm{W}$. \\
\hline$(1-7) \mathrm{Al}$ & igus & 1924 & • & $10 \cdot 4 \mathrm{I}$ & n.p.h. & S. $77^{\circ} \mathrm{W}$. \\
\hline -14) & " & " & 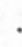 & $3 \cdot 3$ & , & S. $42^{\circ} \mathrm{W}$. \\
\hline $5-21)$ & , & , & & $17 \cdot 9$ & , & S. $71^{\circ} \mathrm{W}$ \\
\hline 2-28) & , & ", & & $9 \cdot 5$ & , & N. $88^{\circ} \mathrm{W}$ \\
\hline Ionth o & $f A$ & & & $10 \cdot 0$ & , & S. $77^{\circ}$ \\
\hline
\end{tabular}


Dungeness (continued in a different form).

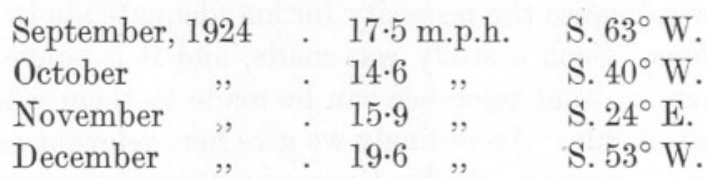

Great Yarmouth. (Residual Winds.)

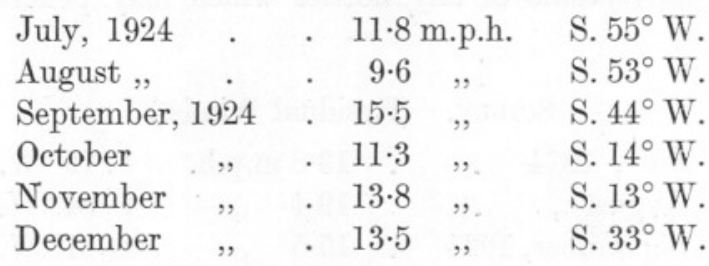

\section{THE RESULTS.}

We shall here tabulate the relevant details as to the movements exhibited by the returned bottles; the positions of recovery are to be referred to the key-chart already given above (Chart 1). It may be noted in this connection that degrees of longitude east of Greenwich are lettered from " $\mathrm{E}$ " to " $\mathrm{Z}$," omitting the letters " I" and " $\mathrm{O}$ "; degrees of longitude west of the prime meridian are lettered "D " to "A," then " ZZ" to "AA," omitting "II" and " OO."

Thus $(0-1)^{\circ}$ East is lettered " $\mathrm{E}$," and $(0-1)^{\circ}$ West is lettered "D."

With regard to the lettering of degrees of latitude, the following is the conventional practice :-

$$
\begin{aligned}
& \left(51-51 \frac{1}{2}\right)^{\circ} \mathrm{N} \text {. is numbered " } 1 . ", \\
& \left(51-50 \frac{1}{2}\right)^{\circ} \mathrm{N} \text {. is numbered " } 51 . \text {." }
\end{aligned}
$$

The reference numbers increase by unity as one moves away from the datum latitude $51^{\circ} \mathrm{N}$. in either direction. It is not necessary here to discuss the origin of this conventional procedure; suffice it to say that it is adopted for reference purposes in the compilation of statistical charts, and we use the method for purposes of convenience.

In the tables which follow; when arriving at the "week from liberation," a fraction of a week counts as one week, e.g. a bottle which was out for 65 days would be entered as recovered in the tenth week.

In the case of bottom bottles only, a double asterisk will be used to indicate all bottles which fulfil all three of the following conditions :-

1. Bottle has wire tail of 20 inches or over.

2. Bottle has been out for 4 weeks or over.

3. Bottle has been taken in a trawl. 
Recoveries From the E3 Liberation UP to 31.5.26.

Fifty surface-floating and 50 bottom-trailing bottles were put out at this position $\left(48^{\circ} 34^{\prime}\right.$ N. $-5^{\circ} 13^{\prime}$ W.) on 10th July, 1924. Up to date, the following returns have been realised :-

$$
\begin{aligned}
& \text { Surface bottles - } 22 \text {, i.e. } 44 \% \text {. } \\
& \text { Bottom bottles - nil. }
\end{aligned}
$$

The recoveries were as here set out.

TABLE I.

\begin{tabular}{|c|c|c|c|c|}
\hline $\begin{array}{l}\text { Weeks from } \\
\text { liberation. }\end{array}$ & $\begin{array}{l}\text { Number } \\
\text { recovered. }\end{array}$ & $\begin{array}{l}\text { Position of } \\
\text { recovery. }\end{array}$ & $\begin{array}{c}\text { No. of , I } \\
\text { days "out." }\end{array}$ & $\begin{array}{l}\text { Distance travelled } \\
\text { (miles). }\end{array}$ \\
\hline \multirow[t]{3}{*}{7} & 14 & C $54 \mathrm{e}$ & 44 & 146 \\
\hline & & C $54 \mathrm{a}$ & , & 145 \\
\hline & & , & , & 143 \\
\hline \multirow[t]{11}{*}{. } & & ", & ", & , \\
\hline & & , & ," & :, \\
\hline & & , & ," & , \\
\hline & & , & , & 144 \\
\hline & & C $53 \mathrm{~g}$ & 45 & 143 \\
\hline & & C $54 \mathrm{a}$ & , & 144 \\
\hline & & ", & , & $"$ \\
\hline & & , & , & " \\
\hline & & ," & 46 & 146 \\
\hline & & , & , & 144 \\
\hline & & ," & 49 & ", \\
\hline \multirow[t]{4}{*}{8} & 4 & , & 50 & 142 \\
\hline & & C $53 \mathrm{~g}$ &, & 147 \\
\hline & & $\mathrm{C} 54 \mathrm{e}$ & , & , \\
\hline & & C 54 a & , & 144 \\
\hline 10 & 1 & B $54 \mathrm{~b}$ & 69 & 121 \\
\hline 24 & 1 & R $16 \mathrm{~d}$ & 165 & 860 \\
\hline 25 & 1 & R 14 b & 170 & 840 \\
\hline 26 & 1 & R $14 \mathrm{c}$ & 181 & , \\
\hline
\end{tabular}

E3. Surface Returns.

ReCOVERIES FROM the E2 Liberation uP to 31.5.26.

The returns from Station E2 are given below. Fifty of each type of bottle were put out, and up to date the following numbers have been recovered :-

Surface bottles - 25 , i.e. $50 \%$.

Bottom bottles - nil. 
Table II.

E2. Surface Returns.

\begin{tabular}{|c|c|c|c|c|}
\hline $\begin{array}{l}\text { Weeks from } \\
\text { liberation. }\end{array}$ & $\begin{array}{l}\text { Number } \\
\text { recovered. }\end{array}$ & $\begin{array}{l}\text { Position of } \\
\text { recovery. }\end{array}$ & $\begin{array}{c}\text { No. of I I } \\
\text { days "out." }\end{array}$ & $\begin{array}{l}\text { Distance travelled } \\
\text { (miles). }\end{array}$ \\
\hline \multirow[t]{2}{*}{4} & 2 & C $53 \mathrm{~g}$ & 26 & 111 \\
\hline & & C $54 \mathrm{a}$ & 24 & 112 \\
\hline \multirow[t]{2}{*}{11} & 2 & $\mathrm{~J} 4 \mathrm{c}$ & 76 & 425 \\
\hline & & $J \quad 5 \mathrm{f}$ & " & 428 \\
\hline \multirow[t]{2}{*}{18} & 2 & $\mathrm{~N} 9 \mathrm{j}$ & 120 & 590 \\
\hline & & $\mathrm{N} 12 \mathrm{~g}$ & , & 630 \\
\hline \multirow[t]{2}{*}{23} & 2 & R 16 a & 158 & 830 \\
\hline & & N $11 d$ & , & 640 \\
\hline \multirow[t]{6}{*}{24} & 6 & Q $18 \mathrm{~h}$ & 168 & 852 \\
\hline & & $\mathrm{R} 17 \mathrm{~g}$ &, & 840 \\
\hline & & , & 163 & , \\
\hline & & R 16 a & 162 & 830 \\
\hline & & $\mathrm{R} 17 \mathrm{~g}$ & 167 & 825 \\
\hline & & R $16 \mathrm{a}$ & 166 & 820 \\
\hline \multirow[t]{4}{*}{25} & 4 & Q $18 \mathrm{e}$ & 172 & 860 \\
\hline & & $\mathrm{Q} 18 \mathrm{~h}$ & ," & 838 \\
\hline & & $\mathrm{K} 17 \mathrm{c}$ & , & 745 \\
\hline & & Q $18 \mathrm{~h}$ & 173 & 855 \\
\hline \multirow[t]{2}{*}{26} & 2 & Q $17 \mathrm{~b}$ & 177 & 835 \\
\hline & & $\mathrm{R} 17 \mathrm{~g}$ & 180 & 825 \\
\hline 27 & 1 & K $19 \mathrm{c}$ & 189 & 815 \\
\hline 28 & 1 & $\mathrm{~K} 16 \mathrm{~b}$ & 194 & 755 \\
\hline \multirow[t]{2}{*}{30} & 2 & $\mathrm{~N} 10 \mathrm{~g}$ & 206 & 595 \\
\hline & & $\mathrm{L} 15 \mathrm{e}$ & 208 & 710 \\
\hline 31 & 1 & $\mathrm{~K} 16 \mathrm{e}$ & 217 & 714 \\
\hline
\end{tabular}

Recoveries from S.SM(c), S.SM(B), and S.SM(a) Liberations up to 31.5.26.

The other three liberating points may be conveniently treated in the order S.SM(c), S.SM(b), and S.SM(a).

$S . S M(c)$. Fifty of each type of bottle were put out on 10/11.7.24 at equal intervals between $49^{\circ} 0^{\prime} \mathrm{N}$. and $48^{\circ} 50^{\prime} \mathrm{N}$. on the route between Southampton and St. Malo. If a north-south line be drawn on a chart from Jersey to the French coast, this "liberating stretch" will be seen to lie slightly to the west of the mid-point thereof.

Returns to date (31.5.26) :-

$$
\begin{aligned}
& \text { Surface. . . . 31, i.e. } 62 \% \text {. } \\
& \text { Bottom . . } 15 \text {, i.e. } 30 \% \text {. }
\end{aligned}
$$


TABle IIIA.

S.SM(c).- SURFACE Returns.

\begin{tabular}{|c|c|c|c|c|}
\hline $\begin{array}{l}\text { Weeks from } \\
\text { liberation. }\end{array}$ & $\begin{array}{l}\text { Number } \\
\text { recovered. }\end{array}$ & $\begin{array}{l}\text { Position of } \\
\text { recovery. }\end{array}$ & $\begin{array}{l}\text { No. of I } \\
\text { days " out." }\end{array}$ & $\begin{array}{l}\text { Distance travelled } \\
\text { (miles). }\end{array}$ \\
\hline 1 & 1 & C $55 \mathrm{e}$ & 7 & 33 \\
\hline \multirow[t]{12}{*}{2} & 13 & C $55 \mathrm{a}$ & 11 & 25 \\
\hline & & C $\stackrel{"}{55 \mathrm{~b}}$ & $\ddot{13}$ & $\ddot{32}$ \\
\hline & & C $54 \mathrm{e}$ & , & 36 \\
\hline & & , & 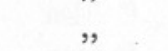 & 35 \\
\hline & & C 54 a & 14 & 36 \\
\hline & & C $54 \mathrm{e}$ & ", & 37 \\
\hline & & $\mathrm{C} 55 \mathrm{~b}$ & 13 & 33 \\
\hline & & , & 14 & , \\
\hline & & " & $"$ & " \\
\hline & & , & $"$ & 32 \\
\hline & & C $54 \mathrm{e}$ & , & 35 \\
\hline & & C $55 \mathrm{e}$ & 13 & 33 \\
\hline \multirow[t]{9}{*}{3} & 9 & C $55 \mathrm{~b}$ & 15 & $"$ \\
\hline & & C 54 e & 16 & 37 \\
\hline & . & C $54 \mathrm{a}$ & ", & , \\
\hline & & ", & 19 & 36 \\
\hline & & C $55 \mathrm{~b}$ & $"$ & 31 \\
\hline & & $"$ & 16 & 33 \\
\hline & & C $54 \mathrm{a}$ & ", & 37 \\
\hline & & C $54 \mathrm{~b}$ & 19 &, \\
\hline & & C $54 \mathrm{e}$ & , & 34 \\
\hline \multirow[t]{5}{*}{4} & 5 & C 54 b & 22 & 37 \\
\hline & & , & 23 & 31 \\
\hline & & C $54 \mathrm{e}$ & 25 & 37 \\
\hline & & C $55 \mathrm{~b}$ & 23 & 31 \\
\hline & & C $54 \mathrm{~h}$ & 24 & 34 \\
\hline 6 & 1 & C $54 \mathrm{e}$ & 41 & 37 \\
\hline 9 & 1 & C $55 \mathrm{~b}$ & 58 & 33 \\
\hline 10 & 1 & C $54 \mathrm{e}$ & 68 & 35 \\
\hline
\end{tabular}


TABLE IIIb.

S.SM(c). Bottom Returns.

\begin{tabular}{|c|c|c|c|c|c|c|}
\hline $\begin{array}{l}\text { Weeks from } \\
\text { liberation. }\end{array}$ & $\begin{array}{l}\text { Number } \\
\text { recovered. }\end{array}$ & $\begin{array}{l}\text { Position } \\
\text { of } \\
\text { recovery. }\end{array}$ & $\begin{array}{l}\text { No. of } \\
\text { days } \\
\text { "out." }\end{array}$ & $\begin{array}{c}\text { Distance } \\
\text { travelled } \\
\text { (miles). }\end{array}$ & $\begin{array}{l}\text { Trawled or } \\
\text { Stranded or } \\
\text { Afloat. }\end{array}$ & $\begin{array}{l}\text { Length of wire } \\
\text { tail on recovery } \\
\text { (inches). }\end{array}$ \\
\hline 3 & 1 & C $54 \mathrm{e}$ & 15 & 35 & Ashore & 8 \\
\hline 7 & 1 & C 54 a & 44 & 39 & , & 13 \\
\hline 9 & 1 & C $54 \mathrm{~h}$ & 61 & 33 & , & $15 \frac{1}{2}$ \\
\hline 10 & 1 & C $54 \mathrm{a}$ & 67 & 37 & , & Not stated \\
\hline 12 & 1 & C $54 \mathrm{e}$ & 79 & , & , & " \\
\hline \multirow[t]{2}{*}{13} & 2 & C $54 \mathrm{a}$ & 90 & , & , & 10 \\
\hline & & B $54 \mathrm{f}$ & 87 & 20 & , & $8 \frac{1}{2}$ \\
\hline 17 & 1 & C $54 \mathrm{e}$ & 115 & 37 & , & None \\
\hline 21 & 1 & C $54 \mathrm{a}$ & 141 & ", & ", & 19 \\
\hline 22 & 1 & D $51 \mathrm{c}$ & 151 & 150 & Not stated & Not stated \\
\hline 25 & 1 & D $51 \mathrm{a}$ & 171 & 139 & Ashore & $14 \frac{1}{2}$ \\
\hline 31 & 1 & C $54 \mathrm{~h}$ & 214 & 37 & , & 12 \\
\hline 37 & 1 & B $54 \mathrm{f}$ & 256 & 32 & " & Not stated \\
\hline \multirow[t]{2}{*}{38} & 2 & B $56 \mathrm{c}$ & 261 & 33 &,${ }^{*}$ & 26 \\
\hline & & B $55 \mathrm{~h}$ & 262 & 17 & , & 18 \\
\hline
\end{tabular}

$S . S M(b)$. Fifty of each type of bottle were put out at equal intervals between $49^{\circ} 35^{\prime} \mathrm{N}$. and $49^{\circ} 20^{\prime} \mathrm{N}$. on the route between Southampton and St. Malo - this on 10/11.7.24. This "liberating stretch" is centred on a point about midway between Jersey and Alderney.

Returns to date (31.5.26) :-

\begin{tabular}{|c|c|c|c|c|}
\hline \multicolumn{2}{|c|}{$\begin{array}{l}\text { Surface. } \\
\text { Bottom. }\end{array}$} & . & \multicolumn{2}{|c|}{$\begin{array}{l}\text {. } \quad 24 \text {, i.e. } 48 \% \text {. } \\
\text {. } 11 \text {, i.e. } 22 \% \text {. }\end{array}$} \\
\hline \multicolumn{5}{|c|}{ TABLE IVA. } \\
\hline & S.SM(в). & SURFACE & Returns. & \\
\hline $\begin{array}{l}\text { Weeks from } \\
\text { liberation. }\end{array}$ & $\begin{array}{l}\text { Number } \\
\text { recovered. }\end{array}$ & $\begin{array}{l}\text { Position of } \\
\text { recovery. }\end{array}$ & $\begin{array}{c}\text { No. of } \\
\text { days "out." }\end{array}$ & $\begin{array}{l}\text { Distance travelled } \\
\text { (miles). }\end{array}$ \\
\hline \multirow[t]{6}{*}{2} & 6 & C 54 a & 9 & 20 \\
\hline & & , & ", & $"$ \\
\hline & & & " & 21 \\
\hline & & C $54 \mathrm{e}$ & 10 & 23 \\
\hline & & C $54 \mathrm{a}$ & ", & 12 \\
\hline & & , & 14 & 11 \\
\hline \multirow[t]{3}{*}{3} & 5 & C $53 \mathrm{~g}$ & 16 & 17 \\
\hline & & C $54 \mathrm{a}$ & , & 19 \\
\hline & & C $53 \mathrm{~g}$ & , & 15 \\
\hline
\end{tabular}




\begin{tabular}{|c|c|c|c|c|}
\hline $\begin{array}{c}\text { Weeks from } \\
\text { liberation. }\end{array}$ & $\begin{array}{l}\text { Number } \\
\text { recovered. }\end{array}$ & $\begin{array}{l}\text { Position of } \\
\text { recovery. }\end{array}$ & $\begin{array}{c}\text { No. of } \\
\text { days "out." }\end{array}$ & $\begin{array}{l}\text { Distance trav } \\
\text { (miles). }\end{array}$ \\
\hline & & C $54 \mathrm{a}$ & 17 & 12 \\
\hline & & C $54 \mathrm{~d}$ & 18 & 21 \\
\hline \multirow[t]{4}{*}{4} & 4 & C $54 \mathrm{a}$ & 24 & 15 \\
\hline & & C $53 \mathrm{~g}$ & 26 & 17 \\
\hline & & , & 25 & , \\
\hline & & C $54 \mathrm{a}$ & 22 & 18 \\
\hline 6 & 1 & C $54 \mathrm{e}$ & 40 & 30 \\
\hline \multirow[t]{3}{*}{11} & 3 & $\mathrm{~J} \quad 4 \mathrm{c}$ & 71 & 340 \\
\hline & & , & " & 344 \\
\hline & & $\mathrm{K} 5 \mathrm{c}$ & 75 & 375 \\
\hline \multirow[t]{2}{*}{14} & 2 & $\mathrm{~J} \quad 5 \mathrm{j}$ & 92 & 355 \\
\hline & & , & 94 & 336 \\
\hline 15 & 1 & N 12 a & 101 & 580 \\
\hline 20 & 1 & $\mathrm{R} 14 \mathrm{~b}$ & 137 & 690 \\
\hline 32 & 1 & $\mathrm{~K} 15 \mathrm{c}$ & 221 & 635 \\
\hline
\end{tabular}

Weeks from Number liberation. recovered.

$\begin{array}{rl}6 & 1 \\ 8 & 1 \\ 9 & 1 \\ 11 & 1 \\ 17 & 1 \\ 19 & 1 \\ 21 & 1 \\ 26 & 1 \\ 28 & 1 \\ 30 & 1 \\ 72 & 1\end{array}$

$\begin{array}{ccccc}\begin{array}{c}\text { Position } \\ \text { of } \\ \text { recovery. }\end{array} & \begin{array}{c}\text { No. of } \\ \text { days } \\ \text { out." }\end{array} & \begin{array}{c}\text { Distance } \\ \text { travelled } \\ \text { (miles). }\end{array} & \begin{array}{c}\text { Trawled or } \\ \text { Stranded or } \\ \text { Afloat. }\end{array} & \begin{array}{c}\text { Length of } \\ \text { tail on reco } \\ \text { (inches). }\end{array} \\ \text { C } 54 \mathrm{a} & 42 & 18 & \text { Ashore } & 13 \frac{1}{2} \\ \text { C } 53 \mathrm{~g} & 51 & , & , & 12 \\ \text {, } & 62 & 16 & , & 14 \\ \text { P 13 c } & 118 & 17 & , & 8 \frac{1}{2} \\ \text { F 1 g } & 127 & 165 & , & \text { nil. } \\ \text { E 51 e } & 145 & 130 & , & , \\ \text { P 14 j } & 182 & 645 & , & ? \\ \text { N 9 b } & 192 & 525 & , & ? \\ \text { J 5 f } & 210 & 350 & , & 19 \frac{1}{2} \\ \text { G 2 j } & 498 & 230 & \text { Trawled } & 12\end{array}$

S.SM(a). Fifty of each type of bottle were put out at equal intervals between $50^{\circ} 20^{\prime} \mathrm{N}$. and $50^{\circ} 5^{\prime} \mathrm{N}$. on the route between Southampton and St. Malo - this on 10/11.7.24. This "liberating stretch" is centred on a point about midway between the Isle of Wight and Alderney.

Returns to date (31.5.26) :-

$$
\begin{aligned}
& \text { Surface . . . } 29 \text {, i.e. } 58 \% \text {. } \\
& \text { Bottom . . } 7 \text {, i.e. } 14 \% \text {. }
\end{aligned}
$$


Table VA.

S.SM(a). Surface Returns.

\begin{tabular}{|c|c|c|c|c|}
\hline $\begin{array}{l}\text { Weeks from } \\
\text { liberation. }\end{array}$ & $\begin{array}{l}\text { Number } \\
\text { recovered. }\end{array}$ & $\begin{array}{l}\text { Position of } \\
\text { recovery. }\end{array}$ & $\begin{array}{c}\text { No. of } \\
\text { days "out." }\end{array}$ & $\begin{array}{l}\text { Distance travelled } \\
\text { (miles). }\end{array}$ \\
\hline \multirow[t]{3}{*}{9} & 3 & $\mathrm{~J} \quad 4 \mathrm{c}$ & 63 & 307 \\
\hline & & $\mathrm{J} \quad 4 \mathrm{f}$ & , & 293 \\
\hline & & $\mathrm{N} 8 \mathrm{a}$ & 61 & 480 \\
\hline \multirow[t]{3}{*}{10} & 5 & $\mathrm{~J} \quad 4 \mathrm{c}$ & 64 & 306 \\
\hline & & " & 65 & $"$ \\
\hline & & $\mathrm{N} " 8 \mathrm{a}$ & 67 & 460 \\
\hline \multirow[t]{2}{*}{11} & 3 & $\mathrm{~J} \quad 4 \mathrm{c}$ & 75 & 307 \\
\hline & & ", & "̈7 & 296 \\
\hline 15 & 1 & $\mathrm{P} 14 \mathrm{j}$ & 101 & 625 \\
\hline 16 & 1 & $\mathrm{R} 14 \mathrm{f}$ & 106 & 685 \\
\hline \multirow[t]{4}{*}{17} & 4 & $\mathrm{R} 14 \mathrm{~b}$ & 114 & 680 \\
\hline & & Q $17 \mathrm{~b}$ & 113 & 710 \\
\hline & & $\mathrm{N} 15 \mathrm{e}$ & 114 & 625 \\
\hline & & $\mathrm{N} 12 \mathrm{a}$ & 115 & 550 \\
\hline 18 & 1 & $\mathrm{R} 13 \mathrm{c}$ & 121 & 710 \\
\hline 19 & 1 & $\mathrm{~K} 15 \mathrm{c}$ & 127 & 590 \\
\hline \multirow[t]{5}{*}{20} & 5 & $\mathrm{~J} 17 \mathrm{f}$ & 137 & 660 \\
\hline & & K 17 a & 135 & , \\
\hline & & K 19 b & 134 & 740 \\
\hline & & L $24 \mathrm{~g}$ & 137 & 890 \\
\hline & & $\mathrm{Q} 17 \mathrm{e}$ & 136 & 715 \\
\hline 24 & 1 & P $28 \mathrm{~g}$ & 165 & 1080 \\
\hline 26 & 1 & $\mathrm{~N} 10 \mathrm{~g}$ & 182 & 490 \\
\hline 27 & 1 & $\mathrm{~N} 25 \mathrm{c}$ & 189 & 990 \\
\hline 28 & 1 & Y $39 \mathrm{j}$ & 190 & 1440 \\
\hline 96 & 1 & Z $39 \mathrm{~g}$ & 672 & 1445 \\
\hline
\end{tabular}




\begin{tabular}{|c|c|c|c|c|c|c|}
\hline \multirow[b]{2}{*}{$\begin{array}{l}\text { Weeks from } \\
\text { liberation. }\end{array}$} & & $\operatorname{S.SM}(\mathrm{A})$. & $\begin{array}{l}\text { Table } \\
\text { Botto }\end{array}$ & $\begin{array}{l}\text { B. } \\
\text { I ReTUR }\end{array}$ & NS. & \multirow[b]{2}{*}{$\begin{array}{l}\text { Length of wire } \\
\text { tail on recovery } \\
\text { (inches). }\end{array}$} \\
\hline & $\begin{array}{l}\text { Number } \\
\text { recovered. }\end{array}$ & $\begin{array}{c}\begin{array}{c}\text { Position } \\
\text { of } \\
\text { recovery. }\end{array} \\
\text {. }\end{array}$ & $\begin{array}{l}\text { No. of } \\
\text { days, } \\
\text { "out." }\end{array}$ & $\begin{array}{c}\text { Distance } \\
\text { travelled } \\
\text { (miles). }\end{array}$ & $\begin{array}{l}\text { Trawled or } \\
\text { Stranded or } \\
\text { Afloat. }\end{array}$ & \\
\hline 9 & 1 & B 52 a & 61 & 35 & Trawled & ca. 12 \\
\hline 11 & 1 & $\mathrm{~J} \quad 4 \mathrm{c}$ & 75 & 307 & Ashore & None \\
\hline 18 & 1 & P $13 \mathrm{c}$ & 125 & 610 & ," & ," \\
\hline 21 & 1 & E $51 \mathrm{c}$ & 142 & 111 & , & 18 \\
\hline 22 & 1 & A $52 \mathrm{~b}$ & 151 & 65 & Trawled & 18 \\
\hline $28 * *$ & 1 & A $52 \mathrm{j}$ & 191 & 55 & , & 24 \\
\hline 30 & 1 & A $53 \mathrm{c}$ & 208 & 56 & Afloat & $12 \frac{3}{4}$ \\
\hline
\end{tabular}

The Returns realised from all Liberations.

Before discussing the results which have just been tabulated, we will consider the returns from the experiment treated as a whole.

Compounding the returns which have been given above for the various places at which bottles were put out, we get :-

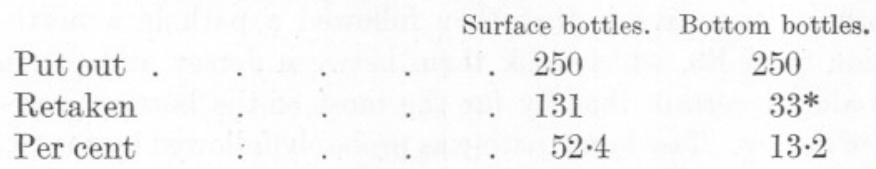

From all the liberating stations the return of surface bottles has been about the same. In the case of the bottom bottles it has been a great disappointment to receive no return from the E3 and E2 liberations; it was due to the desire to await such that publication has been delayed. It is, of course, not yet too late for recaptures of these bottom bottles to be made, but the fact that no returns are yet to hand is a matter for keen regret, as the information which they would have afforded would have been of much more than ordinary interest.

As would be expected from consideration of the respective positions of the Stations S.SM(a), S.SM(b), and S.SM(c), the returns of bottom bottles were greatest in the case of the last and least in the first case- S.SM(b) affording an intermediate number.

\section{DISCUSSION OF THE RESULTS.}

It will be much the most convenient procedure for us to discuss the results from the various liberations separately; we can later devote attention to the wind records when we attempt to summarise the resulting information from all the stations.

\footnotetext{
* Includes one bottle about whose position of liberation doubt exists.
} 


\section{E3.}

(See Table I and Chart 2).

Of the 22 surface bottles returned, those taken within the first 10 weeks (19 bottles) had stranded as follows :-

$$
\begin{array}{r}
14 \text { in C } 54 \text { a. } \\
2, \text { C } 54 \text { e. } \\
2, \text { C } 53 \text { g. } \\
1, \text { B } 54 \text { b. }
\end{array}
$$

The last mentioned refers to a single stranding in Guernsey. All the others (18 bottles) went ashore on the Manche coast; the fastest of them accomplishing its journey of some 145 miles in about 44 days, i.e. at a speed of about $3 \frac{1}{3}$ miles a day. The interesting question is to decide which way the bottles went, whether they skirted the coasts of Brittany, as it were, and then "came up " the Manche coast, or whether they went off straight up Channel and experienced an "indraught" into the Bay of St. Malo, which resulted in the strandings in and around C 54 a. The other alternative is that they followed a path in a north-easterly direction from E3, which took them between Jersey and Guernsey. It seems almost certain that by far the most of the bottles passed to the south of Jersey. This latter path was probably followed by the two bottles which stranded in C 54 e. It seems somewhat strange that only one bottle went ashore on an island. This seems to point to the existence of strong currents washing the shores of Jersey and Guernsey.* The chief point about the E3 surface bottles is, we see, that they nearly all stranded on that part of the Manche coast due east of Guernsey and Sark. A few went ashore (or were found ashore) farther north on the Manche coast, very near to Cap de la Hague. We draw the distinction in the last sentence since it appears probable that the bottles concerned went ashore (or into the shallows) farther south, and were then drifted northwards. Judging from the results of this E3 liberation only, it would seem that there was a strong surface current from the Ushant neighbourhood setting up Channel and impinging on the Manche coast more or less at right angles. It is probable that there was also a strong flow of the surface water from west to east close in to the coast of Brittany; this current, on " coming up against" the Manche coast, can be considered to give rise to a piling-up tendency which is relieved by the escape of the water as a north-going, fringing surface current up the coast in question. The existence of such a current would go far to explain the distribution of the stranded E3 surface bottles, for they were found

\footnotetext{
* The tides in this area are notoriously strong.
} 


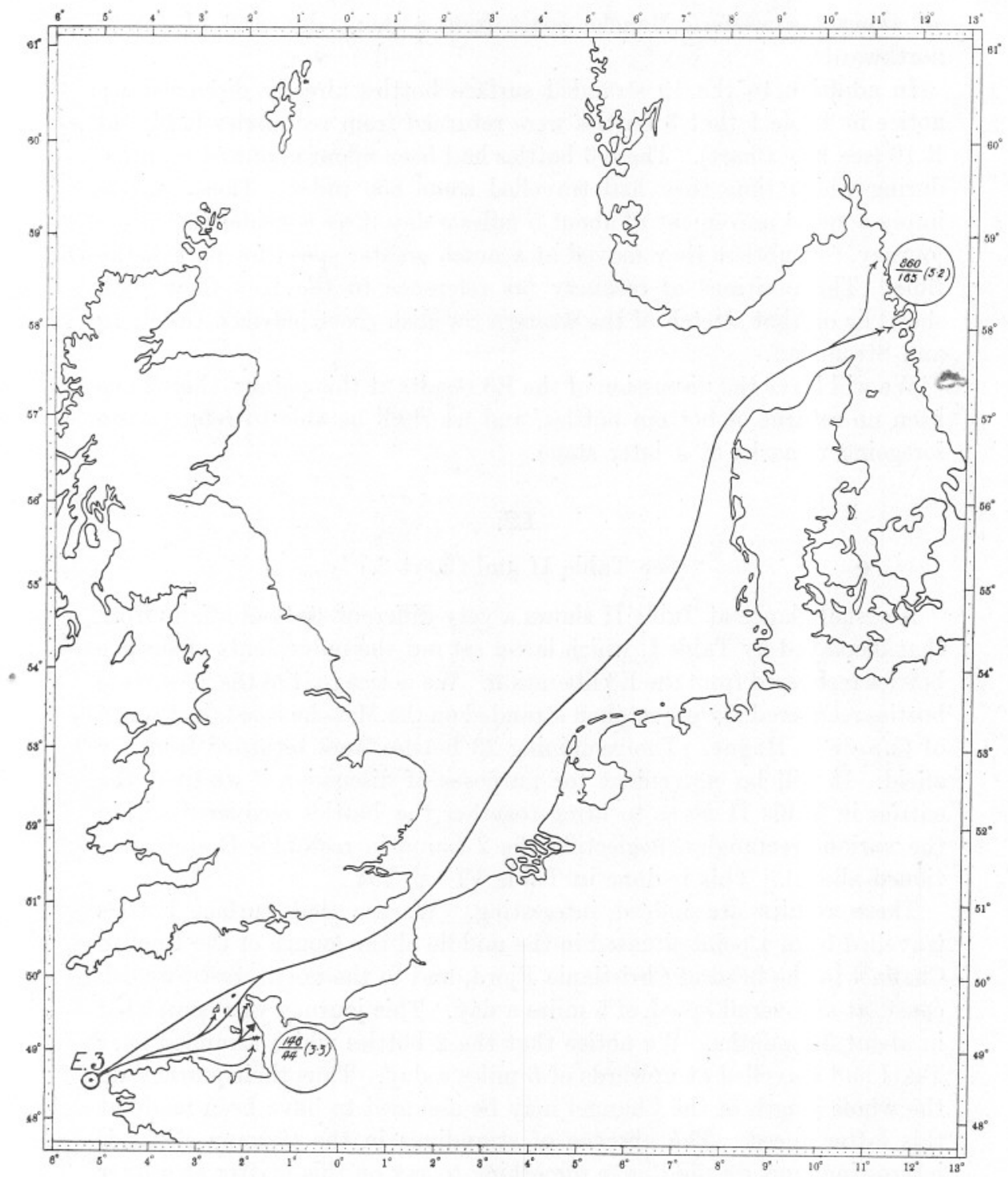

CHART 2.

Illustrating the actual movements of the surface bottles put out at Station E3 on 10 July, 1924. Where the arrows are multi-barbed, the number of barbs denotes the number of bottles recovered at the place indicated - save that the solid triangular barb refers to 14 bottles. The figures in the circles refer to the stranding places near by, and have the following signification:-

The numerator indicates chordal distance travelled in miles.

The denominator gives the time "out" (in days) of the fastest bottle.

The bracketed figures denote the corresponding speed in miles per day. NEW SERIES.-VOL. XIV. No. 3. MARCH, 1927. 
all along the western Manche coast from a point due east of Jersey northwards.

In addition to the 19 stranded surface bottles already discussed we notice in Table $I$ that 3 bottles were returned from rectangles $\mathrm{R} 14$ and R 16 (see Key Chart). These 3 bottles had been afloat about $5 \frac{1}{2}$ months, during which time they had travelled some 850 miles. These travels imply a speed movement of about 5 miles a day if we consider the whole journey. Doubtless they moved at a much greater speed for part of the time. The positions of recovery (as reference to the Key Chart will show) lie on that stretch of the western Swedish coast between Goteborg and Stromstad.

$\therefore$ We will leave the discussion of the E3 results at this point; there have been no returns of bottom bottles, and we shall be able to refer to the foregoing remarks at a later stage.

E2.

(See Table II and Chart 3.)

A casual glance at Table II shows a very different state of affairs from that displayed by Table I, which latter set out the movements of surface bottles recovered from the $\mathrm{E} 3$ liberation. We notice that of the 25 surface bottles recovered, 2 were retaken stranded on the Manche coast, just south of Cap de la Hague. The remaining 23 bottles were returned from far afield. It will be convenient for purposes of discussion if we treat the entries in Table II so as to bring together the bottles recovered within the various rectangles (neglecting the 2 found in rectangle $\mathrm{C}$ and mentioned above). This is done in Table VI-p. 704 .

These results are indeed interesting. We see that surface bottles travelled from a point situated in the middle of the mouth of the English Channel to the head of Christiania Fjord, and to the north-west Swedish coast, at an overall speed of 5 miles a day. This journey was completed in about $5 \frac{1}{2}$ months. We notice that the 2 bottles which stranded near Texel had travelled at upwards of 5 miles a day. Thus their journey up the whole length of the Channel may be assumed to have been made at this latter speed. The absence of strandings in the German Bight is interesting, and we shall have something to say on this matter at a later stage. The bottle which stranded in $\mathrm{L} 15 \mathrm{e}$ is not very significant in point of speed, since it may have lain undiscovered for a considerable time. Again the " $\mathrm{K}$ " bottles were returned from the Dutch islands, and we notice that their time "out" is a variable quantity. There is a considerable likelihood of bottles being unnoticed in such places; their apparent defective speed, as compared with bottles which went ashore elsewhere, seems insignificant therefore. There were no bottom returns 


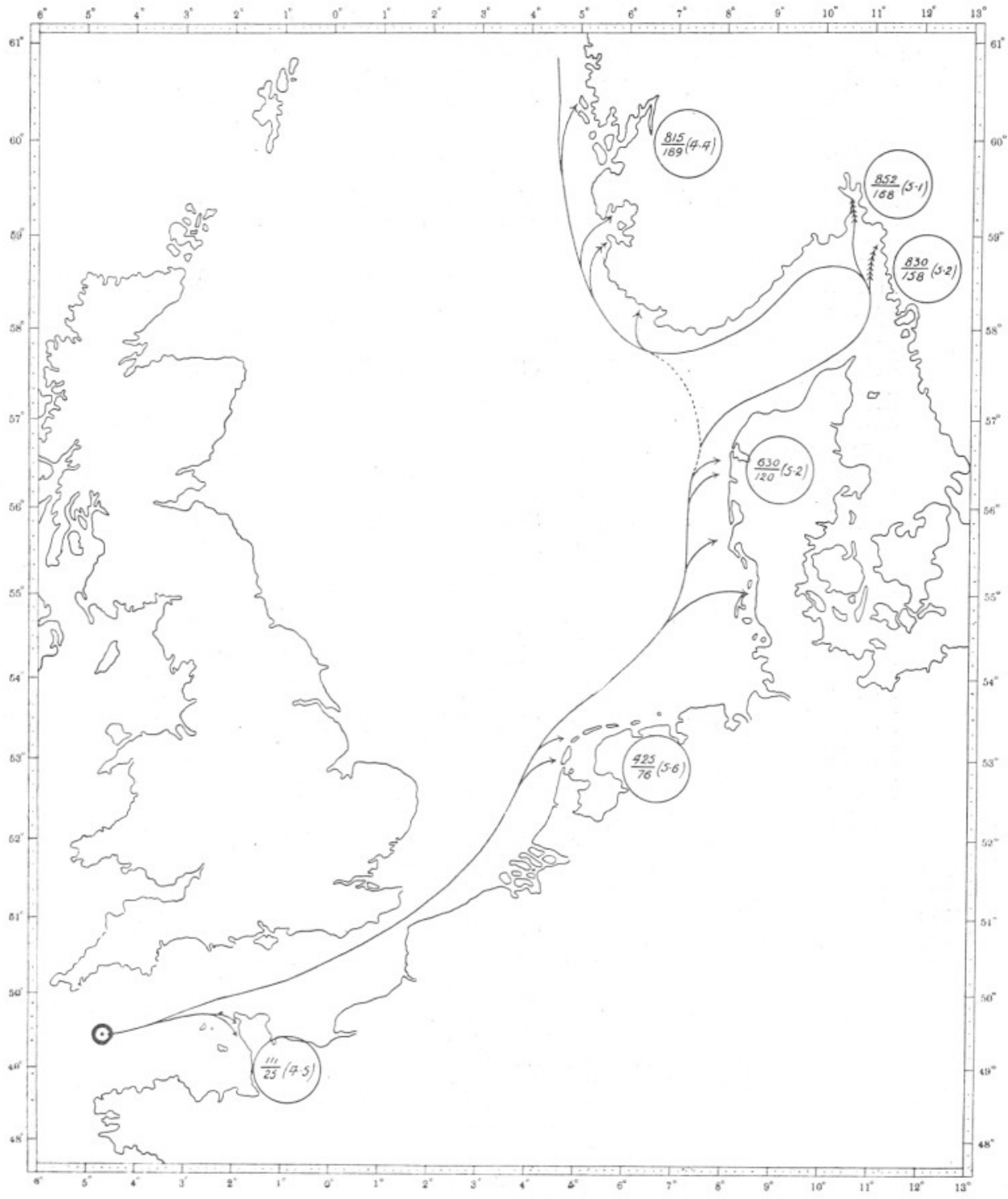

CHART 3.

Illustrating the actual movements of surface bottles put out at Station E2 on 10 July, 1924. Where the arrows are multi-barbed, the number of barbs denotes the number of bottles recovered at the place indicated. The figures in the circles refer to the stranding places near by, and have their previous signification. 


\section{TABLE VI.}

\begin{tabular}{|c|c|c|c|c|}
\hline $\begin{array}{l}\text { Rectangle and } \\
\text { sub-rectangle. }\end{array}$ & $\begin{array}{l}\text { Number } \\
\text { of bottles. }\end{array}$ & $\begin{array}{c}\text { Distance travelled.* } \\
\text { Miles. }\end{array}$ & $\begin{array}{c}\text { Time* “out." } \\
\text { Days. }\end{array}$ & $\begin{array}{c}\text { Speed.* } \\
\text { Miles per day }\end{array}$ \\
\hline $\left.\begin{array}{ll}J & 4 \mathrm{c} \\
\mathrm{J} & 5 \mathrm{f}\end{array}\right\}$ & 2 & 425 & 76 & $5 \frac{3}{5}$ \\
\hline K17 c & & & & \\
\hline $\left.\begin{array}{l}\mathrm{K} 19 \mathrm{c} \\
\mathrm{K} 16 \mathrm{~b} \\
\mathrm{~K} 16 \mathrm{e}\end{array}\right\}$ & 4 & 745 & 172 & $4 \frac{1}{3}$ \\
\hline $\begin{array}{l}\text { L } 15 \mathrm{e} \\
\mathrm{N} 9 \mathrm{j})\end{array}$ & 1 & 710 & 208 & $3 \frac{2}{5}$ \\
\hline $\left.\begin{array}{l}\text { N } 12 \mathrm{~g} \\
\text { N } 11 \mathrm{~d} \\
\text { N } 10 \mathrm{~g}\end{array}\right\}$ & 4 & 630 & 120 & $5 \frac{1}{4}$ \\
\hline $\left.\begin{array}{l}\text { Q } 18 \mathrm{~h} \\
\text { Q } 18 \mathrm{~h} \\
\text { Q 17 b } \\
\text { R } 16 \mathrm{a} \\
\text { R } 17 \mathrm{~g} \\
\text { R } 17 \mathrm{~g}\end{array}\right\}$ & 5 & 852 & 168 & 5 \\
\hline 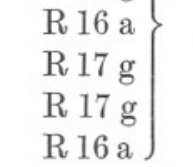 & 7 & 830 & 158 & $5 \frac{1}{4}$ \\
\hline
\end{tabular}

in the case of this liberation, so that we may conclude our discussion of it at this point; we shall revert to it when we try to draw up a general picture to represent the results of the whole experiment.

\section{S.SM (c.)}

(See Tables IIIA and IIIв and Charts 4 and 5.)

\section{Surface Bottles.}

In this case there were returned 31 surface bottles and 15 bottom bottles; we shall first discuss the surface returns (see Chart 4).

The entries in Table IIIA are singularly monotonous in point of recovery position. Every returned surface bottle is seen to have stranded in one or other of the two rectangles, C 54 and C 55. The average distance covered by the bottles prior to stranding was some 34 miles; the speed

* The tabulated values refer to the fastest bottle of each group. 
is not easy to estimate. We can, however, adopt as representative the speed of the fastest bottle-a procedure which is quite justified, and which has customarily been used in reporting on previous experiments. In this connection attention is to be devoted to the bottle which stranded in $\mathrm{C} 55 \mathrm{e}$, after moving 33 miles in not more (though possibly less) than 7 days. This, of course, points to a minimum "straight line" speed of just under $4 \frac{3}{4}$ miles a day, as applicable to the surface currents in the area concerned. An observation worthy of notice is that the fastest

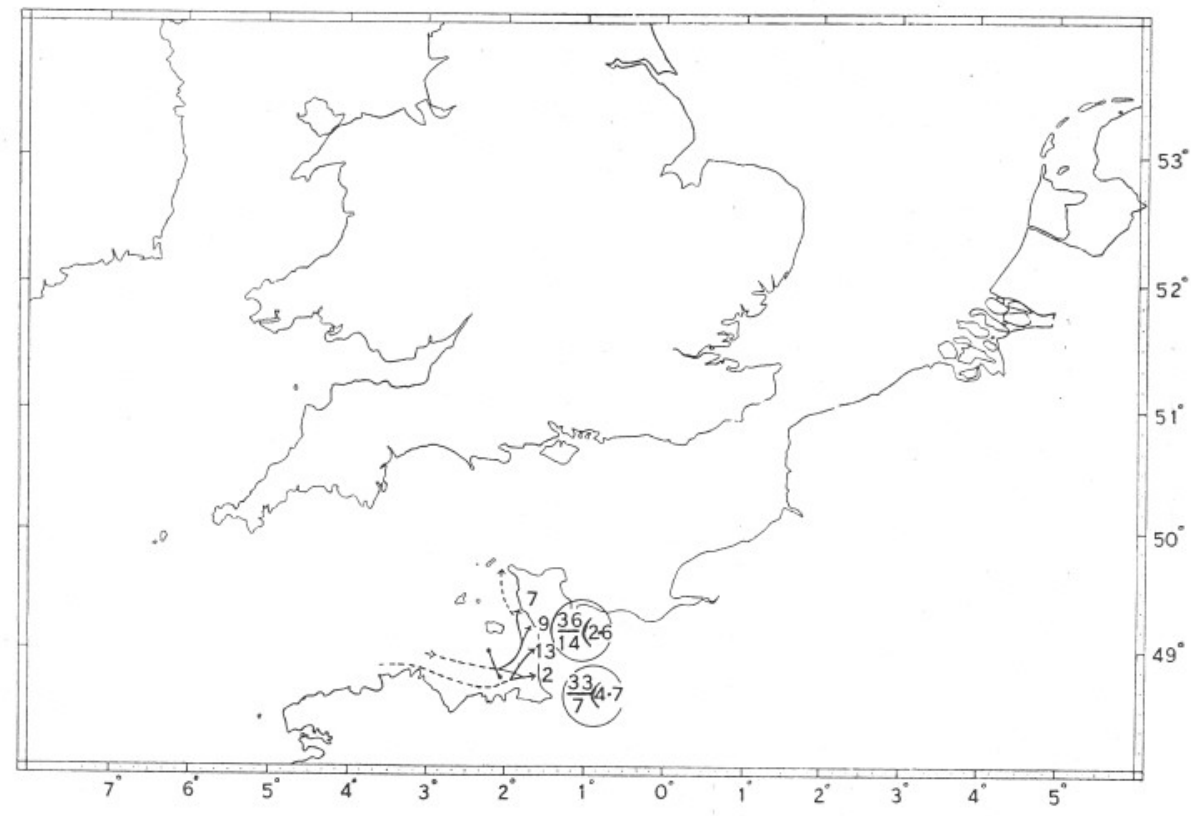

CHART 4.

Illustrating the actual movements of surface bottles put out at Station S.SM(c) on 10-11 July, 1924. The tips of the arrows indicate stranding places, the small figures near the coastline refer to the numbers of bottles recovered there, and the figures inside the circles have the usual signification.

C 55 bottle was retaken ashore before the fastest C 54 bottle. This fact seems to indicate that the currents flow almost due east, thereby creating a piling-up tendency on the western Manche shore, which tendency is relieved by a fringing coastal flow of surface water to the northward. In this connection attention may be drawn to the fact that the stranded surface bottles were distributed all the way up the western coast of the Manche department, though none rounded Cap de la Hague. Should any further returns come to hand in the future they will be particularly useful, if it be found that they had made their way out of 
the bay. Certain features in the nature of negative evidence may be remarked upon; thus, there were no strandings in Jersey. This is very significant, since Jersey is only some 10 miles to the north of the liberating stretch, S.SM(c). Also no bottle was found ashore anywhere on the French coast to the southward and westward of the subrectangle, C 55 e. These facts, in conjunction with the results of the strandings of surface bottles from the E2 and E3 liberations, can fruitfully be compared with

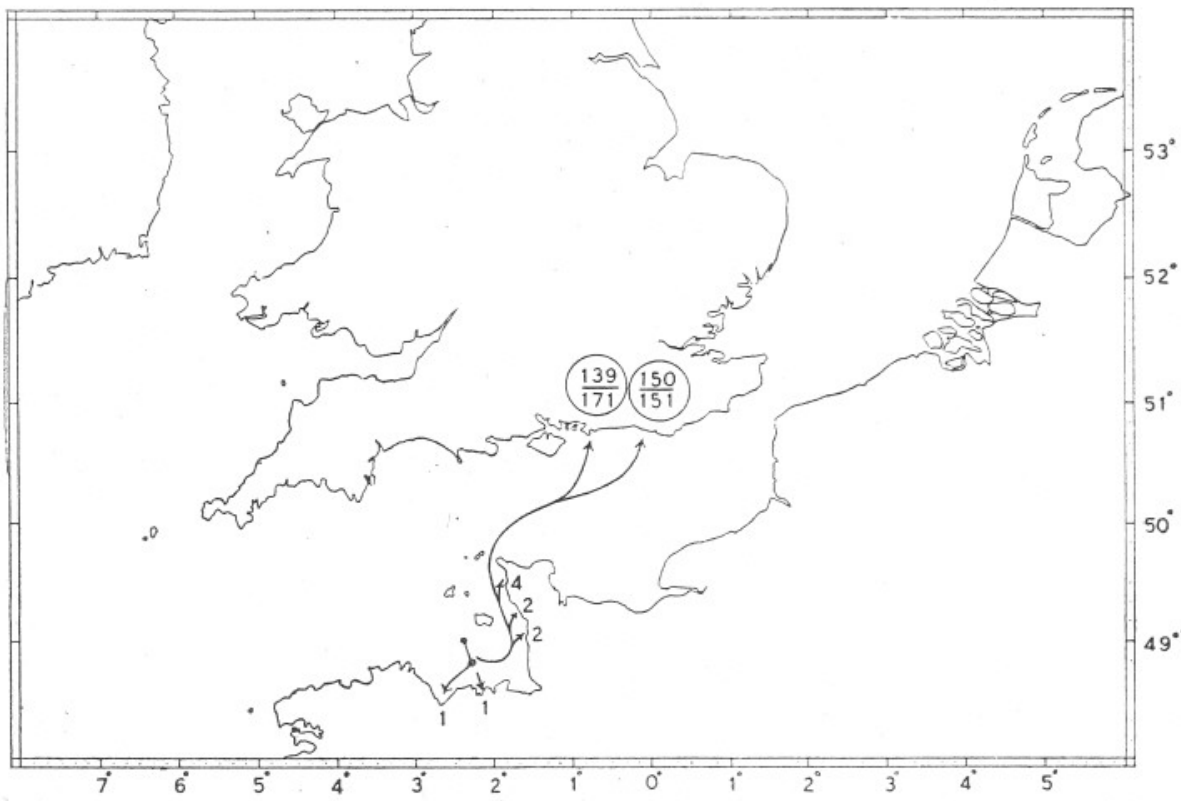

CHART 5.

Showing the actual movements of bottom bottles put out on 10-11 July, 1924, at S.SM(c). The arrows illustrate the deduced movements of the bottom water. Where figures appear near the coastline they denote the number of bottles which went ashore at the places indicated. The figures in circles refer to the bottles recovered near by, and have the following signification :-

Numerator denotes miles travelled.

Denominator denotes days out.

the information presented on Admiralty Chart 327 (q.v.). There it is seen that evidence has resulted, from past experiments, of a surface current coming up Channel from seawards of Ushant, and having a definite offset into the Bay of St. Malo. Arrows are noticed which indicate the occurrence of a definite set on the French coasts around Paimpol, St. Brieuc, and St. Malo. Our present experiments yield no evidence of this, and it will be necessary for us later to pay some 
regard to the prevalent wind conditions which (there is a priori evidence to suppose) may afford some measure of explanation.

\section{Bottom Bottles. (Chart 5.)}

Fifteen of the 50 bottom bottles put out were returned in all. With one exception, it is safe to assume that they were all genuine bottom trailers. The exception referred to is the bottle which stranded at the position, C 54 e, after travelling 35 miles in 15 days; this speed (which is minimal by reason of the fact that the bottle may have lain undiscovered for some time) forces one to the conclusion that the bottle was a faulty one which floated-a not uncommon experience. We may consider first the bottles which were recovered at the least distance from the place of putting out. First, we notice that one bottle (recovered at B $56 \mathrm{c}$ ) had moved south by east and stranded on a river bank, after penetrating some way up the estuary. Another bottle (found at B $55 \mathrm{~h}$ ) had moved towards south by west, and had stranded on the French coast in the neighbourhood of St. Brieuc. Two bottles moved in an east-north-easterly direction and went ashore on the eastern extremity of Jersey. Eight bottles stranded on the western Manche coast, and of these more were recovered at the most northerly position than at those farther south. This seems to point to a movement of the bottom water off the western Manche coast, towards north. There remain two very interesting bottles which were returned after having stranded on the Sussex coast - one on the western side of Selsey Bill and the other near Brighton. The faster of these had performed the journey of some 150 miles in about as many days. Such movements as were taken on by the bottom bottles put out at S.SM(c) could, therefore, be explained by assuming that within the area enclosed by a line drawn from Cap de la Hague to Paimpol, the bottom water moved at the time of the experiment as follows :-

There was a set towards south on to the coast between St. Brieuc and St. Malo; some little distance east of this there was a set towards north with an easterly element "in it." The movements of the bottom bottles within this area could be explained if we assumed the existence of a bottom current coming from the west somewhat south of the fortyninth parallel, which, on reaching about $2^{\circ} 30^{\prime}$ west longitude, bifurcates, one branch trending north-north-easterly and the other southerly and south-easterly. This latter branch, on impinging on the coast around St. Brieuc, must be considered to flow towards east, and then to follow the Manche coast. Thus we should have a bottom "swirl" in the eastern part of the bay - the opposite thing to the "buchtwirbeln" of Böhnecke. 


\section{$\operatorname{S.SM}(b)$. \\ (See Tables IVA and IVB and Charts 6 and 7.)}

From the liberations made at this position, 24 surface and 11 bottom bottles were recovered. We will discuss the surface ones first.

\section{Surface Bottles. (See Chart 6.)}

A casual glance at the table of returns (IVA) shows by no means the same monotony as did the corresponding table for S.SM(c). All bottles recovered within the first 6 weeks had stranded within the two rectangles, C 54 and C 53, but later recoveries were from far afield. Let us confine our attention, for the time being, to the 16 bottles which went ashore on the Manche coast. First, we may notice certain features of the liberating stretch, S.SM(b) :-

In part, it is open to the westward ; part of it lies between Guernsey and the French Manche coast ; and part of it lies opposite to the " strait" between Guernsey and Jersey. These facts (in view of our finding, from the movements of bottles put out elsewhere at the same time, that there was a current coming from the west) make it appear at least possible that bottles, put out at different points on the 15-mile stretch, might encounter different conditions of current. Of the 16 bottles in question, 9 went ashore in C $54 \mathrm{a}, 1$ in $\mathrm{C} 54 \mathrm{~d}, 2$ in $\mathrm{C} 54 \mathrm{e}$, and 4 in $\mathrm{C} 53 \mathrm{~g}$. Thus there was a marked surface set towards the east. The fastest bottles attained a minimal speed of some $2 \frac{1}{4}$ miles a day. No bottle stranded anywhere on the Manche coast south of that part abreast of Jersey. The 2 bottles which stranded in $\mathrm{C} 54$ e were put out at the southernmost part of the S.SM(b) liberating stretch, and the slight southerly element in their easterly movement is, no doubt, due to a southward bend in the surface current, coming from the westward, in rounding Jersey.

The fact that so many bottles stranded in C $54 \mathrm{a}$ and $\mathrm{C} 53 \mathrm{~g}$ points again to the existence of a flow of the surface water up the Manche coast in a northerly direction. In fact, there seems to have been, at the time of the experiment, a pronounced flow against the whole of the western Manche coast, which necessitated a surface escape to the northward.

\section{The far-travelled Surface Bottles.}

Five bottles were recovered stranded on the Dutch islands, off the Zuider Zee, after covering a distance of from 340 to 375 miles. The speed attained was of the order of 5 miles a day. One had gone ashore near the entrance to the Lim Fjord, in Jutland, after accomplishing a journey of 580 miles in 101 days (possibly less). One went ashore north of Goteborg, in Sweden, after travelling some 690 miles in 137 days : the overall 


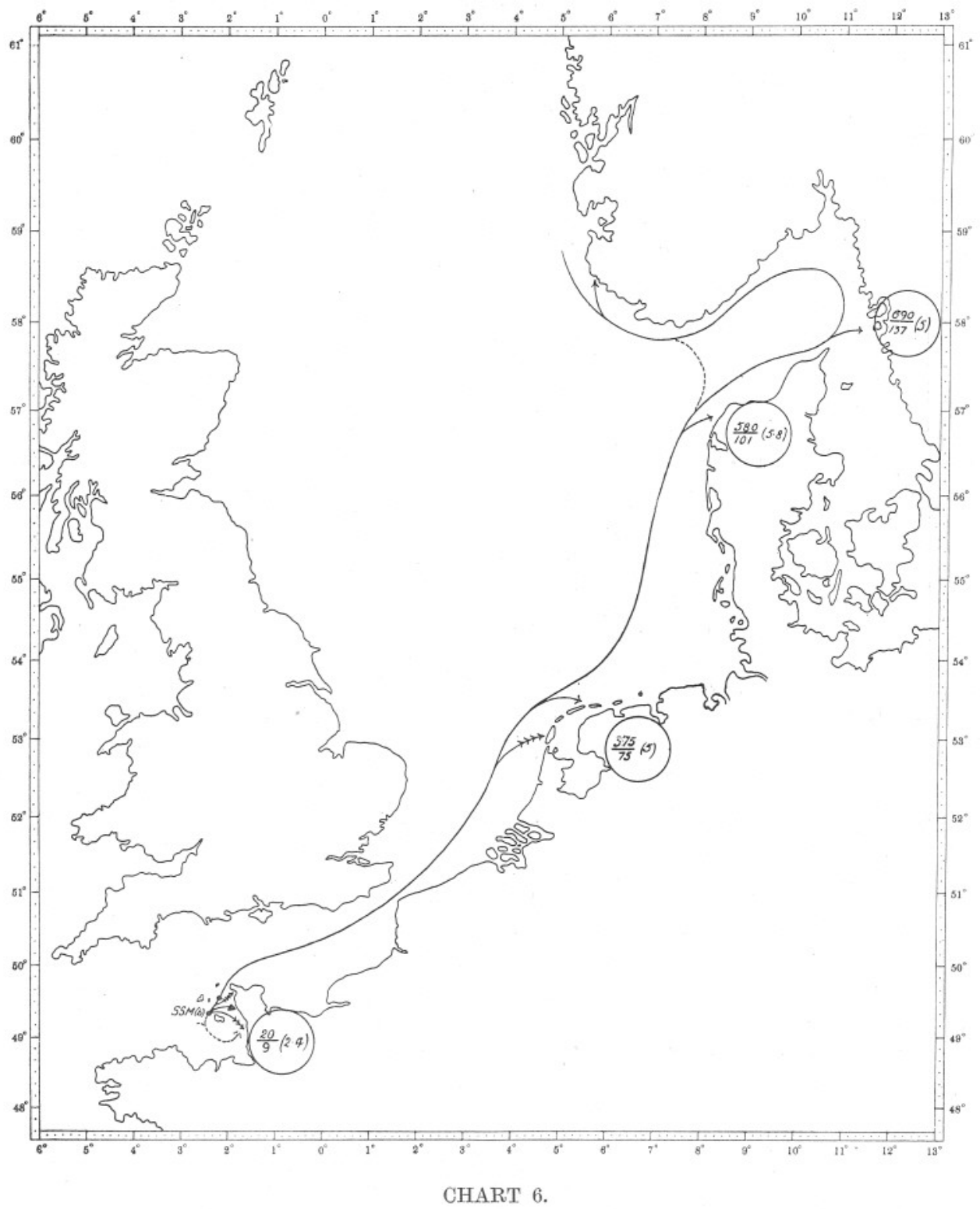

Mllustrating the actual movements of surface bottles put out at Station S.SM(b) on 10-11 July, 1924. The signification of the arrows and figures in circles is the same as on preceding charts, save that the solid triangular barb refers to 9 bottles. 
speed for this long journey was approximately 5 miles a day. The remaining bottle was cast ashore in S.W. Norway, just north of Ekersund. It may have gone first (it probably did) into the Skager-Rack and Cattegat.

\section{The Bottom Bottles. (See Chart 7.)}

Of the 11 bottom bottles returned, only 1 had been retaken by trawl; the others were cast ashore. The direction of movement of the bottom

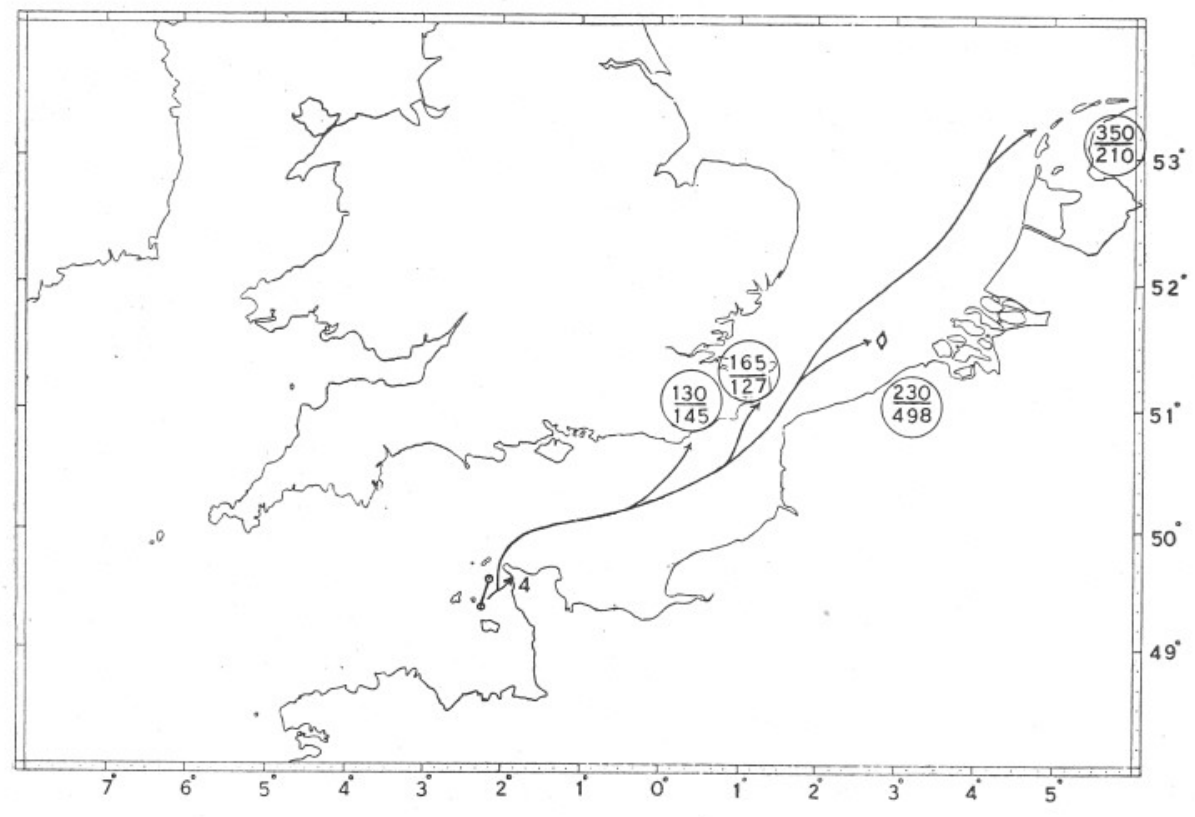

CHART 7.

Illustrating the actual movements of bottom bottles put out at S.SM(b) on 10-11 July, 1924. The arrows indicate the deduced direction of the bottom currents, and the various symbols have their usual signification, save that:-

4 refers to four bottl ss which stranded; the fastest of these had gone 18 miles in 42 days (at most), and

$\uparrow$ denotes position at which one bottle was retaken by trawl.

water seems to have been in almost exact accord with that of the surface water. Four bottles went ashore on the western Manche coast; they moved due eastwards at a rate of slightly less than half a mile a day. The others, which were subsequently returned, had rounded Cap de la Hague and gone up Channel towards the North Sea. The bottle recovered in P $13 \mathrm{c}$ was undoubtedly a faulty one which floated-as witness its high speed, which is the same as that attained by the surface bottles. The same can be said of those bottles which were returned from P 14 j 
and $\mathrm{N} 9 \mathrm{~b}$, respectively. This leaves us with 4 bottles calling for comment. One stranded near Beachy Head, after moving some 130 miles in 145 days; one went ashore on the Kent coast east of Dungeness, after having travelled 165 miles in 127 days; one was trawled in G 2 j (near Bligh Bank) in the Southern Bight, after a journey of some 230 miles in 498 days; whilst the other had stranded on an island off the Zuider Zee, after moving 350 miles in some 210 days. The journeys performed by the fastest bottles point to a bottom water movement up Channel, towards the North Sea, of about a mile a day.

\section{S.SM (a.)}

(See Tables $V_{A}$ and $V_{B}$ and Charts 8 and 9.)

From the liberations made here, 29 surface and 7 bottom bottles have been recovered. We will, as has been our custom above, first discuss the former.

\section{Surface Bottles. (See Chart 8.)}

Not one surface bottle was returned from any place on the Channel coasts. Those bottles, which had moved least far, were recovered stranded on Texel and neighbouring islands, and on the Dutch coast near Helder. In all, 8 bottles went ashore in rectangle $\mathrm{J} 4$, and, of these, 7 were recovered in $\mathrm{J} 4 \mathrm{c}$ - the other had stranded in $\mathrm{J} 4 \mathrm{f}$. These bottles had travelled some 300 miles in just over 60 days; their overall speed for the entire journey can be taken as 5 miles a day. Next, in point of distance travelled, are 3 bottles which stranded in Sylt (N 8 a), of which one completed a journey of some 480 miles in about 60 days. This corresponds to a representative straight line speed over the whole distance of about eight miles a day. Another bottle was cast ashore near Blavands Huk after a journey of 490 miles in 182 days. There were 2 more strandings in Jutland: 1 bottle just north of Lim Fjord and the other near Hirtshals; the latter had covered some 550 miles (at least) in 115 days. The remaining 15 surface returns were from even farther afield.

Three bottles went ashore on the Swedish coast, north of Goteborg, after performing a journey of some 680 miles in just over 100 days; 2 bottles stranded at the head of Christiania Fjord, after travelling some 700 miles in as little as 113 days (possibly less). There was one recovery from the Skager-Rack coast of Norway (near Christiansand Fjord) : in this case the distance travelled was 625 miles, and the time occupied 114 days. The remaining returns from the Norwegian coast to the number of 9 are as follows : 1 from near Ekersund (590 miles in 127 days), 2 from the neighbourhood of Stavanger (660 miles in some 135 days), 1 from near Bergen (740 miles in 134 days), and 5 more from places farther north 


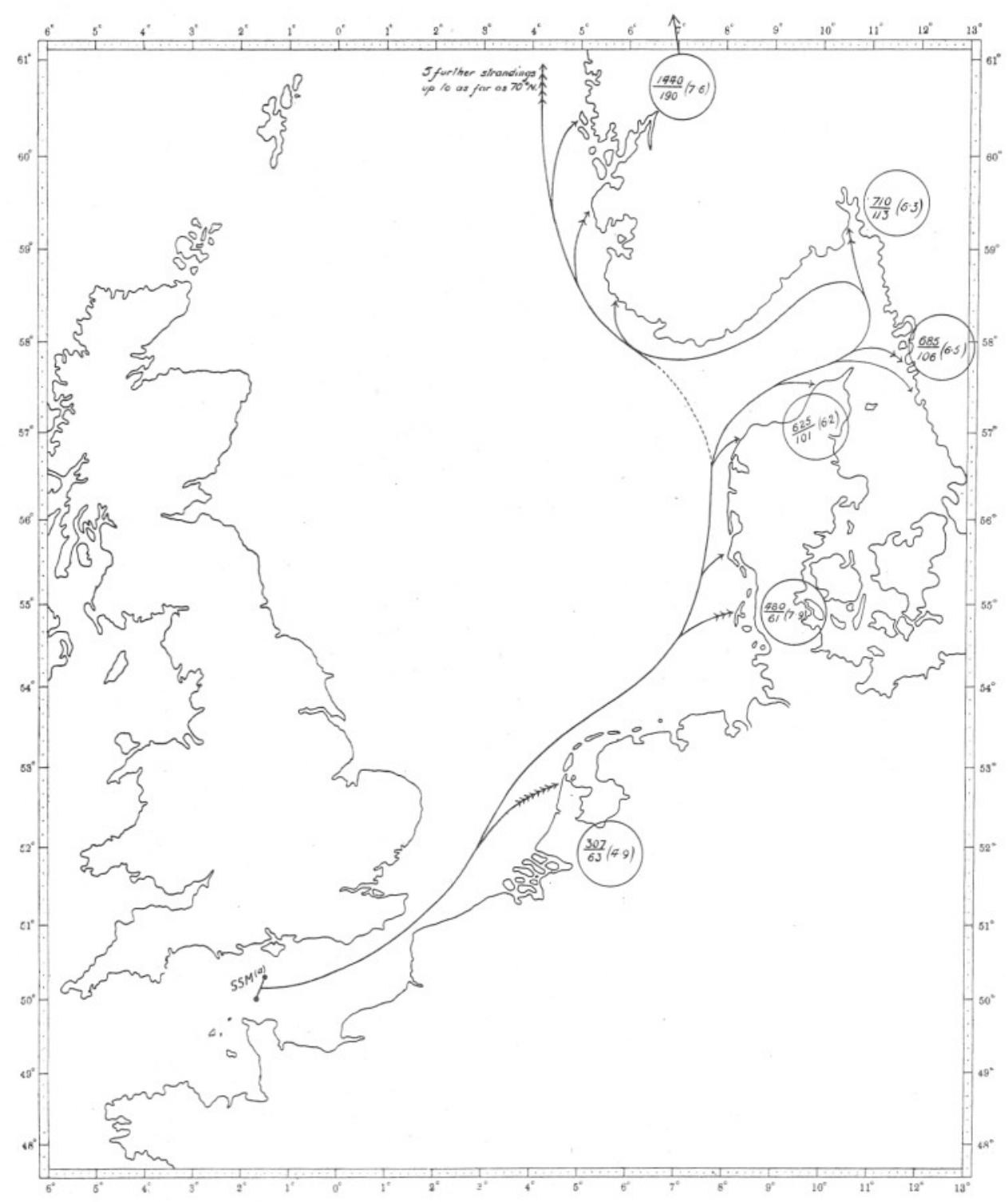

CHART 8.

Illustrating the actual movements of surface bottles put out at Station S.SM(a) on 10-11 July, 1924. The arrows and figures have their usual signification. 
up to $70^{\circ} \mathrm{N}$. The farthest travelled bottles of all had gone ashore north of Tromso, 1 having been returned from the island of Senyen. One bottle had travelled 1440 miles, at least, since it was put out, and had performed this journey in some 190 days; this implies the amazing overall speed of some $7 \cdot 6$ miles a day.

\section{The Bottom Bottles. (See Chart 9.)}

Seven bottom bottles were returned as shown in Table $V_{\text {B }}$ above. Their movements are of great interest, and, as already remarked, it is

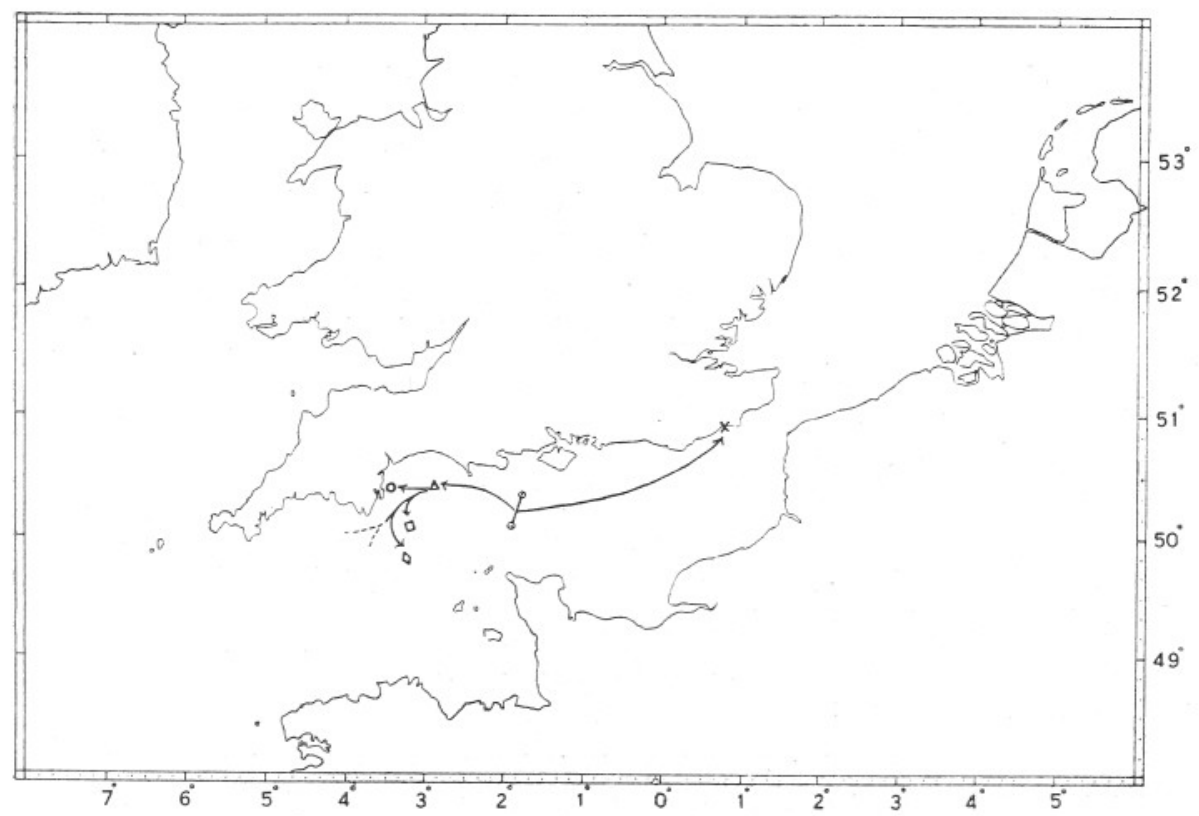

CHART 9.

Illustrating the actual movements of bottom bottles put out at Station S.SM(a) on 10-11 July, 1924. The arrows indicate the deduced direction of bottom-water movement, the various symbols denote positions of recovery, and represent the following journeys :-

$$
\begin{aligned}
& \chi \quad . \quad .111 \text { miles in } 142 \text { days (at most). }
\end{aligned}
$$

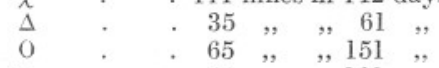

$$
\begin{aligned}
& \text { 口 . } .55,,, 191, \\
& \text { ८ . } \quad 56 \text { (at least) }, 208,
\end{aligned}
$$

a matter for keen regret that as yet no returns have been realised from the E2 liberations for comparative purposes. If we omit the two bottles ( $\mathrm{J} 4 \mathrm{c}$ and $\mathrm{P} 13 \mathrm{c}$ ), which were without doubt faulty bottles which floated, 
we find that of the 5 remaining bottles recovered, 4 were retaken to the westward of the position of liberation and the other near Dungeness. It is always extremely difficult to arrive at any useful idea as to the speed of the bottom currents from the movements of the bottom bottles, as these will certainly be carried along at a speed considerably in defect of that of the transporting current. We see from the table $(\mathrm{VB})$ that the bottle which stranded near Dungeness did so after a journey which points to an overall speed of movement of something less than 1 mile a day. The other 4 bottles, in having moved towards the west, present us with a problem of no little interest; in this connection, the fact that such S.SM(b) bottom bottles as rounded Cap de la Hague went towards east, would suggest that there may be, as it were, "a parting of the ways " in respect of the bottom-water movements in mid-Channel about longitude $2^{\circ} \mathrm{W}$. Thus it may be that to the north of the fiftieth parallel there is a west-going bottom set, and to the south of it a set in the opposite direction. This matter is worthy of discussion, and it will be well to see if we can find any reference to it in earlier work. Harvey (6, p. 73) refers to the results obtained from a liberation of bottom-trailing drift. bottles in May, 1921, at the routine Station E1, which is situated approximately 25 miles S.S.W. (true) from Plymouth (about $50^{\circ}$ N. $-4^{\circ} 20^{\prime}$ W.). It was found that a movement of bottom water to the westward takes place at times. The present writer has also shown reason to suppose that the bottom water as far east as the Isle of Wight (in latitude $50^{\circ} \mathrm{N}$.) can, at times, exhibit a westerly movement (see 5, p. 37, Chart 16). The Charts drawn up by Lumby to illustrate the water circulation in the English Channel, during winter (February) and summer (August) of 1922, must be referred to here (13, Fig. V, opp. p. 12). Lumby's opinions may be summarised thus:-

Winter. Draw a line from Prawle Point to the mid-point of a line joining Lizard Head to Ushant, and produce it seawards. Then, on the north-west side of this line there exists a cyclonic circulation of the entire water column, whilst on the south-east side, there is a decided flow (comprehending the whole water column) from seawards up Channel.

Summer. Seawards of the Land's End-Ushant line is a pronounced northerly flow of surface water, flanked on the west by a cyclonic circulation involving the entire water column. This " cyclone" is elongated in a north by west to south by easterly direction. Now join Prawle Point to Ushant, and Land's End to Ushant, and a triangular area is defined, which "harbours" what may conveniently be described as resembling the eastern half of a cyclonic circulation involving both surface and bottom water. A rectangular area, of which the north Brittany and east Normandy coasts are two sides, "harbours" a large anticyclonic 
surface swirl. There is a surface offset from this, east of the St. Alban's Head to Cap de la Hague line, which flows on up Channel towards the North Sea. Lumby further infers the existence of a continuous bottom flow up the entire length of the Channel, from west to east. These results of Lumby's are deductions from salinity distribution.

The results of our present experiments, considered together with the findings of Harvey and Carruthers just referred to, seem to point to the following conclusion a propos of the circulation of the bottom water in the areas discussed :- If we join the position of Station E2 to the midpoint between the Isle of Wight and Alderney, and consider the area defined by our line, so drawn, and the English coast, then we infer the existence therein of a cyclonic bottom water circulation - the " cyclone" being attenuated in an east-west direction.

What happens in and off the Bay of St. Malo is a vexed question indeed. Lumby would invest this area with a large anticyclonic surface circulation; the compilers of Admiralty Chart 327 infer a strong surface flow up Channel, with frequent pronounced surface insets into the bay. The views arrived at as a result of the present experiments can best (to avoid endless discussion) be presented in the form of a summary chart (see Charts 10a and 10b), which shall set forth the resulting information from the present experiments as a whole.

The Water Movements considered in Relation to the Wind.

(See Wind Tables, p. 691.)

The winds, as recorded at Scilly, were, during the whole of July, August, September, and October, overwhelmingly from the south-west quadrant. For the first three of these months the residuum of wind was from W.S.W. (true).

The winds of July and August, as recorded at Guernsey, were also overwhelmingly south-westerly, and so they were according to the Dungeness records.

Furthermore, the winds, as recorded at Yarmouth for the entire period of July to December inclusive, were from this same direction and that markedly.

The results of all past work would, in view of these wind conditions, lead us to expect what we have found, viz. that there existed a very pronounced surface set right up Channel towards the North Sea, and thereafter right across the southern North Sea towards the Skager-Rack. The frequent strandings of surface bottles on the Swedish and southern Norwegian coasts shows how marked was the Jutland current in autumn, for the bottles which so stranded would be "off" the Skager-Rack about 
the end of October. This entry of surface water into the Skager-Rack in autumn has been remarked upon before $(10$, p. 46$)$, and Pettersson has remarked that westerly winds favour the flow of the Jutland current. It seems to be hardly a fruitful matter to spend much time seeking any numerical correlation between wind speed and surface current speed; in the open ocean, where tidal streams do not call for much consideration, the search for such inter-relationship is more profitable perhaps. However, if we can obtain a useful representative value for wind force over a suitable period, we may be able to arrive at some idea of the numerical relationship between the two quantities in question.

Our present results do not provide us with really suitable material, for we should need to know the movements of bottles which were put out at different times, and which performed their travels during the prevalence of different wind conditions. Such material was forthcoming from Garstang's experiments, already referred to (4), and he was able to advance a formula connecting wind and drift. He established a connection between the two quantities :-

(a) Number of miles drifted.

(b) Resultant pressure of the wind.

A high degree of consistency between drifts deduced from his equivalent and the movements actually performed by his bottles was obtained by Garstang. This worker was of opinion that an expression of the formula,

$$
\mathrm{V}=\mathrm{MW} \text {, }
$$

where $\mathrm{V}=$ velocity of the water drift produced by a wind of velocity $\mathrm{W}$, and $\mathrm{M}$ is a constant, could not be fitted to the results of actual experiment. Formulæ of this type had been advanced by H. Mohn and others ; Garstang criticises Mohn's equation on the ground that it applies to currents sustained by a given wind and not to currents produced from rest. R. Witting, * like Garstang, decided that a formula of the type :

$$
\mathrm{V}=\mathrm{M} \mathrm{W}
$$

was unsuitable, and he came to the conclusion that the formula,

$$
\mathrm{V}=\mathrm{M} \mathrm{W^{ \frac {1 } { 2 } }}
$$

was better. The relationship arrived at by Witting (with modern velocity equivalents of Beaufort numbers) would stand thus :-

$$
\mathrm{V}=0.44 \mathrm{~W}^{\frac{1}{2}}
$$

$\mathrm{V}$ and $\mathrm{W}$ being in $\mathrm{cm}$. per sec. Witting had arrived at this relationship as a result of investigating a large number of observations made at Finnish lightships.

\footnotetext{
* Quoted by Matthews, p. 680 (8).
} 
It will be of some interest if we ascertain what constant results from fitting our present bottle travels to a formula of this latter type $\left(\mathrm{V}=\mathrm{M} \mathrm{W}^{\frac{1}{2}}\right)$. In our case the contemporaneity of the bottle liberations, together with the fact that the same wind conditions hold for all bottles, forbids us to attempt the establishment of a relationship. If we wish to evaluate the constant M we must have available :-

(a) A reliable value for current speed.

(b) A really representative value for wind speed.

Now in an area like the English Channel, where strong tidal streams occur, these two desiderata must be of a comprehensive nature, i.e. any accepted current speed must (in regard to drift bottles, at any rate) be estimated on the dual basis of a long journey accomplished and a considerable time out. Similarly our accepted wind speed must, of necessity, be the resultant for a considerable period. In the case of $(a)$ we can get what we want from Chart 8 , where we see that surface bottles had moved a very long way (over 600 miles in some cases) at a speed of $6 \frac{1}{2}$ miles a day and over. The information as to $(b)$ is not so easy to obtain even though we have, at an earlier point in this paper, made a full study of the winds at several observing places. We should welcome, in this connection, a continuous autographic wind record for some suitably placed station. We fortunately have access to such. The excellent meteorological reports of the Eastbourne County Borough Council provide just what is needed. The logged winds, estimated according to Beaufort's Scale, accord well with the records from the stations which we have already employed. In the Eastbourne report for 1924 there is a table of wind movements as recorded by the Indicating Cup Anemometer, and we find that the mean winds were as follows during those months of 1924 which interest us :-

\begin{tabular}{|c|c|c|c|c|c|c|c|}
\hline July & . & ${ }^{\circ}$ & . & $204 \cdot 211$ & ailes & per & \\
\hline August & . & ${ }^{\circ}$ & . & $219 \cdot 87$ & , & , & " \\
\hline September & . & . & 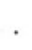 & $216 \cdot 06$ & , & " & $"$ \\
\hline October & . & . & . & $200 \cdot 41$ & , & , & \\
\hline November & . & . & . & $202 \cdot 82$ & ", & , & ", \\
\hline
\end{tabular}

These records are very consistent amongst themselves, though they differ very markedly from the winds for the preceding six months of the year. Let us now solve for $\mathrm{M}$ by using the $\mathrm{V}$ and $\mathrm{W}$ values already arrived at. We get

$$
\begin{aligned}
6.5 & =\mathrm{M} 208^{\frac{1}{2}} \\
\text { whence } \mathrm{M} & =0 \cdot 45 .
\end{aligned}
$$

We thus find that the relationship between wind speed and surface NEW SERIES. - VOL. XIV. No. 3. MARCH, 1927. 
current speed in respect of our far-travelled bottles (provided both quantities be expressed in miles per day*) is :-

$$
\mathrm{V}=0.45 \mathrm{~W}^{\frac{1}{2}}
$$

where $\mathrm{V}$ represents current and $\mathrm{W}$ wind. This equation is almost identical with that found by Witting, who found it convenient to estimate both wind speed and current speed in $\mathrm{cm}$. per sec., and whose formula applies to this unit. If we convert our wind and current values from miles per day into $\mathrm{cm}$. per sec., we find that the constant of the formula becomes $0 \cdot 3$ instead of $0 \cdot 45$.

\section{ACKNOWLEDGMENTS.}

Thanks are due and are here expressed to the following :-

To the writer's colleague, Mr. H. Stokes, for preparing the final printer's copies of the charts from drafts supplied.

To all the officers of the Southern Railway Company's Marine Department for the welcome co-operation which rendered possible the carrying out of part of the experiments.

\section{SUMMARY OF RESULTS.}

In July, 1924, 250 floating, and an equal number of bottom-trailing, bottles were put out at selected places in the western English Channel. Fifty of each type were put out at each of the two routine Stations E2 and E3, and the same number was "liberated " at each of three selected stretches along the steamship route from Southampton to St. Malo. Those surface bottles, which did not strand locally, travelled rapidly up Channel towards the North Sea and across it. Many bottles arrived in the Skager-Rack after performing their journey of some 700 miles at the rate of 6 miles a day and more. An adequate study of wind conditions, as recorded at several stations along the length of the Channel and at one station in the southern North Sea, revealed the fact that there was, for some $5 \frac{1}{2}$ months (counting from the time of liberation of the bottles), an almost uninterrupted predominance of south-westerly winds-as recorded at all stations considered. The whole area of the Channel was swept by south-westerly winds of average speed of some 9 miles a day for at least $5 \frac{1}{2}$ months subsequent to the time of putting out of the bottles. July, 1924, had (according to the Falmouth Observatory records) the largest proportion of westerly winds experienced for 54 years ; 20 days of this month had winds with westerly components. The association of

* It will have been noticed that $V$ is in sea miles per day, whilst $W$ is in ordinary miles per day. No conversion was made, since the value of $V$ depends upon an estimate of distance travelled which can at best be only approximate; the latter is probably considerably under-estimated, as it is substantially a straight line estimate. 


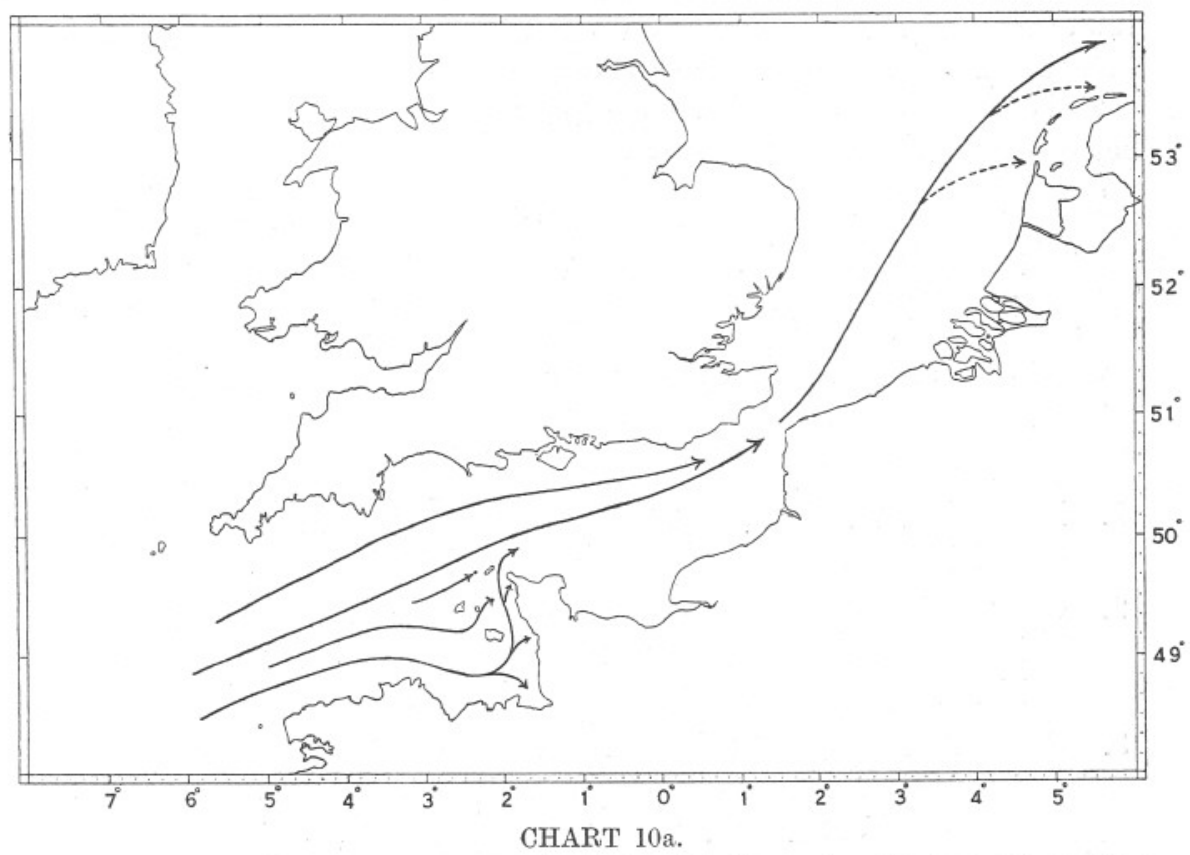

Showing the surface-water movements in the English Channel, as illustrated by bottles put out in July, 1924.

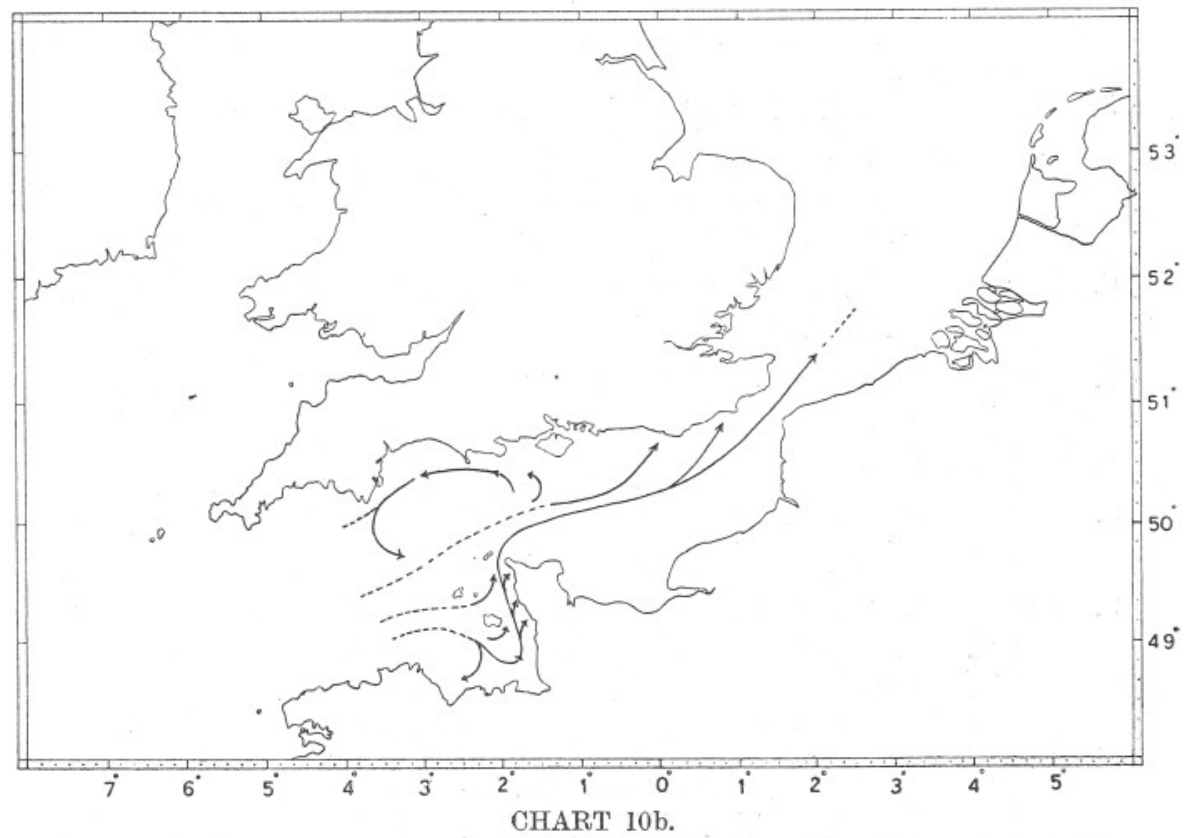

Showing the bottom-water movements in the English Channel as illustrated by bottles put out in July, 1924. 
the unusually persistent westerly winds with the rapid travel of surface bottles towards and across the North Sea is interesting.

The chief feature of interest regarding the information yielded by the bottom bottles is the following :-

There seems to be in longitude $2^{\circ} \mathrm{W}$. (approximately) a parting of the ways in respect of the movements of the bottom water. To the north of $50^{\circ} \mathrm{N}$. latitude there appears to be a west-going bottom set, whereas to the south of this parallel there is a set in an easterly direction.

Charts 10a and 10b embody the results of the experiments.

\section{LITERATURE CITED.}

1. Fulton, T. W. "The Currents of the North Sea and their Relation to Fisheries." 15th Annual Report. Fish Board Scotl.

2. Gilson, G. Quoted from a review in Journal du Conseil (Conseil Permanent International Pour l'Exploration de la Mer). Vol. 1, No. 1. Copenhagen, 1926.

3. Gilson, G. "Exploration de la Mer sur les Côtes de Belgique." Mémoires du Musée Royal d'Histoire Naturelle de Belgique. Mémoire No. 35. III. " Recherches sur la Dérive dans la Mer du Nord." 1, Expériences ; II à XIII Bruxelles, 1924.

4. Garstang, W. "Report on the Surface Drift of the English Channel and neighbouring Seas during 1897." Journ. Mar. Biol. Assoc., N.S., Vol. V, No. 2. April, 1898.

5. Carruthers, J. N. "The Water Movements of the North Sea in relation to the geographical distribution of Post-Larval Herring." Appendix to Fish. Invest. Ser. II, Vol. VII, No. 4. 1924, Ministry of Agric. and Fisheries.

6. Harvey, H. W. "Hydrography of the English Channel." Cons. Internat. Rap. et Proc. Verb. XXXVII. 1925.

7. Genrke, J. "Mean Velocity of the Atlantic Currents running North of Scotland and through the English Channel." Pub. de Circ., No. 40. Copenhagen, 1907.

8. Matthews, D. J. "Physical Oceanography," in Dictionary of Applied Physics, Vol. III. London, 1923.

9. Heldt, H. "Les courants de Marée au Bateau-Feu du Sandettié." Off. Sci. et Tech. des Pêches Maritimes. Notes et Mémoires, No. 27, 1923.

10. Carruthers, J. N. " The Water Movements in the Southern North Sea." Part 1. The Surface Drift. Min. of Agric. and Fisheries. Fish. Invest. 1I, Vol. VIII, 2. 1925. 
11. Carruthers, J. N. "The Water Movements in the neighbourhood of the English Channel-North Sea Junction." Drift Bottle Experiments. Journ. Mar. Biol. Assoc., XIII, p. 665, 1925.

12. Bidder, G. P. "Account of some Experiments on BottomTrailers." Cons. Inter. Rap. et Proc. Verb. IV, 1905.

13. Lumby, J. R. " The Salinity and Water Movements in the English Channel and Southern Bight during the period 1920-23." Min. of Agric. and Fisheries, Fish. Invest. Ser II, Vol. VII, No. 7. 1924. 
